\title{
Eugenol and its Synthetic Analogues Inhibit Cell Growth of Human Cancer Cells (Part I)
}

\author{
H. Carrasco A., ${ }^{*}, a$ L. Espinoza C., ${ }^{b}$ V. Cardile, ${ }^{c}$ C. Gallardo, ${ }^{b}$ W. Cardona, ${ }^{a}$ \\ L. Lombardo, ${ }^{c}$ K. Catalán M., ${ }^{b}$ M. Cuellar F. ${ }^{e}$ and A. Russo ${ }^{d}$
}

\author{
${ }^{a}$ Departamento de Ciencias Químicas, Universidad Andrés Bello, Campus Viña del Mar, Viña del Mar, Chile \\ ${ }^{b}$ Departamento de Química, Universidad Técnica Federico, Av. España $N^{\circ} 1680$,
} Santa Maria, Valparaiso, Chile

${ }^{c}$ Department of Physiological Sciences, University of Catania, V.le A. Doria 6, 95125, Catania, Italy

${ }^{d}$ Department of Biological Chemistry, Medical Chemistry and Molecular Biology, University of Catania, V.le A. Doria 6, 95125, Catania, Italy

${ }^{e}$ Facultad de Farmacia, Universidad de Valparaíso, Av. Gran Bretaña $N^{\circ} 1093$, Valparaíso, Chile

Propriedades antioxidante e anticancerígena foram relatadas para o Eugenol (4-alil-2metoxifenol) (1). Na tentativa de aumentar a atividade intrínseca deste composto natural, alguns derivados foram sintetizados. O eugenol foi extraído do óleo de cravo da Índia e seus análogos (2-6) foram obtidos por reações de acetilação e nitração. Eugenol (1) e seus análogos (2-6) foram avaliados in vitro frente a duas linhagens de células de câncer humanas: DU-145 (células de câncer de próstata, insensíveis a andrógeno) e KB (células de carcinoma escamoso oral). A viabilidade celular foi avaliada por ensaios com sal de tetrazólio. A liberação de desidrogenase lática (LDH) também foi investigada para avaliar a toxicidade celular como um resultado do rompimento celular subseqüente à ruptura da membrana. Todos os compostos apresentaram atividade inibitória sobre o crescimento das células cancerosas examinadas. Os resultados obtidos demonstram que os compostos 5-alil-3-nitrobenzeno-1,2-diol (3) e acetato de 4-alil-2-metoxi-5-nitrofenol (5) foram significativamente mais ativos que o eugenol $(p<0,001)$, com valores de $\mathrm{IC}_{50}$ em células DU-145 de $19,02 \times 10^{-6}$ e $21,5 \times 10^{-6} \mathrm{~mol} \mathrm{~L}^{-1}$ respectivamente, sugerindo que a presença dos grupos nitro e hidroxila podem ser importantes na atividade destes compostos. Os resultados também parecem indicar que a morte por apoptose está sendo induzida em células KB e DU-145. Nas condições experimentais avaliadas, não foi observado qualquer aumento estatisticamente significativo na liberação de LDH pelas células de câncer quando tratadas com eugenol e seus análogos.

Eugenol (4-allyl-2-methoxyphenol) (1) has been reported to possess antioxidant and anticancer properties. In an attempt to enhance intrinsic activity of this natural compound, some derivatives were synthesized. Eugenol was extracted from cloves oil and further, the eugenol analogues (2-6) were obtained through acetylation and nitration reactions. Eugenol (1) and its analogues (2-6) were examined by in vitro model of cancer using two human cancer cell lines: DU-145 (androgeninsensitive prostate cancer cells) and KB (oral squamous carcinoma cells). Cell viability, by tetrazolium salts assay, was measured. Lactic dehydrogenase (LDH) release was also investigated to evaluate the presence of cell toxicity as a result of cell disruption, subsequent to membrane rupture. In the examined cancer cells, all compounds showed cell-growth inhibition activity. The obtained results demonstrate that the compounds 5-allyl-3-nitrobenzene-1,2-diol (3) and 4-allyl2-methoxy-5-nitrophenyl acetate (5) were significantly $(p<0,001)$ more active than eugenol, with $\mathrm{IC}_{50}$ values in DU-145 cells of $19.02 \times 10^{-6}$ and $21.5 \times 10^{-6} \mathrm{~mol} \mathrm{~L}^{-1}$, respectively, and in KB cells of $18.11 \times 10^{-6}$ and $21.26 \times 10^{-6} \mathrm{~mol} \mathrm{~L}^{-1}$, respectively, suggesting that the presence of nitro and hydroxyl groups could be important in the activity of these compounds. In addition, our results seem to indicate that apoptotic cell demise appears to be induced in KB and DU-145 cells. In fact, in our experimental conditions, no statistically significant increase in LDH release was observed in cancer cells treated with eugenol and its analogues.

Keywords: eugenol, synthesis, DU-145 cancer cells, KB cancer cells, cell viability, lactic dehydrogenase $(\mathrm{LDH})$ release 


\section{Introduction}

Eugenol (4-Allyl-2-methoxyphenol) (Scheme 1), a main constituent of the essential oil obtained from commonly consumed spices such as Pimenta racemosa (bay leaves), Cinnamomum verum (cinnamon leaf) and Syzygium aromaticum (clove), is used as antiseptic, antibacterial, analgesic agent in traditional medical practices. ${ }^{1}$ Now, it is used in pharmaceutical and food products and in beverages as a flavoring agent. ${ }^{2}$ The therapeutic benefits of eugenol are well known. In recent times, it has been studied for a variety of promising biological properties. It has been reported to participate in photochemical reactions and to possess insecticidal, antioxidant and anti-inflammatory activities. . $^{3,4,5}$ Eugenol has been demonstrated to inhibit prostaglandin biosynthesis and to block COX-2 activity (1). It is important that in several studies, this natural compound was reported to be non genotoxic and non carcinogenic. In long term carcinogenicity experiments by various groups in CD-1 mice and F344 rats, eugenol was not associated with tumor formation. ${ }^{1}$ In addition, it was found to be protective against many genotoxins and carcinogens, biochemical studies in mice and rats have demonstrated its role as an effective inducer of detoxifying phase II enzymes. ${ }^{2}$ Recently, an anticancer activity was hypothesized. Preclinic studies have demonstrated that eugenol induces a reactive oxygen species-mediated apoptosis in HL-60 human promyelocytic leukemia cells and causes melanoma growth suppression through inhibition of E2F1 transcriptional activity. ${ }^{6,1}$ In view of these experimental evidences on anti-tumor properties of eugenol, to enhance intrinsic activity of this natural compound. In the present work, five derivatives were synthesized and the prepared compounds were tested for cell-growth inhibition activity towards DU-145 (androgen-insensitive prostate cancer cells) and KB (oral squamous carcinoma cells) human tumor cell lines.

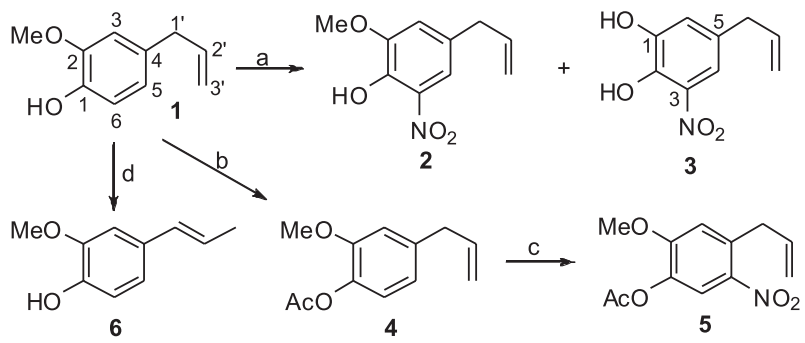

Conditions: a. $\mathrm{NaNO}_{3} / \mathrm{KHSO}_{4}, \mathrm{SiO}_{2} / \mathrm{H}_{2} \mathrm{O}(1: 1), \mathrm{CH}_{2} \mathrm{Cl}_{2}$, rt, 5.5 h., C.C., $63.2 \%(2), 2.9 \%$ (3); b. Ac $\mathrm{Ac}_{2} \mathrm{O} / \mathrm{py} / \mathrm{DMAP}, \mathrm{CH}_{2} \mathrm{Cl}_{2}, \mathrm{rt}, 30 \mathrm{~min} .98 \%$; c. $\mathrm{HNO}_{3} / \mathrm{H}_{2} \mathrm{SO}_{4}, \mathrm{CH}_{2} \mathrm{Cl}_{2}, 0^{\circ} \mathrm{C}, 30$ min., C.C., recrys. $35 \%$;

d. $\mathrm{KOH} / \mathrm{HOCH}_{2} \mathrm{CH}_{2} \mathrm{OH}$, reflux, $5 \mathrm{~h}, 85 \%$.

Scheme 1. Synthesis of eugenol derivatives.

\section{Experimental}

\section{General}

Unless otherwise stated, all chemical reagents were purchased with the highest commercially available purity (Merck or Aldrich) and were used without previous purification. Melting points were measured on a StuartScientific SMP3 apparatus and are uncorrected. IR spectra were recorded as thin film or $\mathrm{KBr}$ pellets in a Nicolet Impact 420 spectrometer. $v_{\max }$ values are expressed in $\mathrm{cm}^{-1} .{ }^{1} \mathrm{H}$ and ${ }^{13} \mathrm{C}$ NMR spectra were recorded in $\mathrm{CDCl}_{3}$ solutions and referenced to the residual peak of $\mathrm{CHCl}_{3}$ at $\delta 7.26$ ppm and $\delta 77.00 \mathrm{ppm}$ for ${ }^{1} \mathrm{H}$ and ${ }^{13} \mathrm{C}$, respectively, on a Bruker Avance 400 Digital NMR spectrometer, operating at $400.1 \mathrm{MHz}$ for ${ }^{1} \mathrm{H}$ and $100.6 \mathrm{MHz}$ for ${ }^{13} \mathrm{C}$. Chemical shifts are reported in $\delta$ ppm and coupling constants $(J)$ are given in Hz. HRMS were recorded on a MAT 95XP, Thermo Finnigan spectrometer and represented as $m / z$ (\% rel. int.). Silica gel (Merck 200-300 mesh) was used for CC and silica gel plates and HF-254 for TLC. Spots were detected on TLC by heating after spraying with $25 \%$ $\mathrm{H}_{2} \mathrm{SO}_{4}$ in $\mathrm{H}_{2} \mathrm{O}$.

\section{Synthesis}

Eugenol (1) was obtained from cloves essence, according to standard procedure. ${ }^{10}$ Previously our investigation group reported the synthesis, spectroscopic analysis and crystalline structure of compound 5. ${ }^{11}$ Isoeugenol (6) was obtained by isomerization from eugenol according to the procedure previously described with modifications, extending the reaction time to 5 hours. Eugenol (1) and its analogues (2-6) are showed in Scheme 1. ${ }^{12}$

4-Allyl-2-methoxy-6-nitrophenol (2) and 5-allyl-3nitrobenzene-1,2-diol (3): Eugenol $1.5 \mathrm{~g}$ (9.15 mmol) was dissolved in dichloromethane $(30 \mathrm{~mL})$ and was added to a mixture which contained $4.5 \mathrm{~g}(33 \mathrm{mmol})$ of potassium hydrogen sulphate, $3.0 \mathrm{~g}(35.3 \mathrm{mmol})$ of sodium nitrate and $3.5 \mathrm{~g}$ of wet silica to $50 \% \mathrm{P} / \mathrm{P}$; the mixture was left with constant stirring at room temperature for 5.5 hours. The complete disappearance of the starting product was confirmed by thin layer chromatography (TLC) (AcOEt: $n$-hexane 1:3). The reacted mixture was filtered through silica and the solid was washed with dichloromethane, and the solvent evaporated in vacuum to give a reddish oil. Pure product was obtained after chromatografic column (5:1 - 3:1 AcOEt in hexane), which gave $1.10 \mathrm{~g}$ of the desired compound 2 (63.2\% yield) and $0.043 \mathrm{~g}$ (2.9\%) of $\mathbf{3}$. Compound 2 (oil): IR (film) $v_{\max } / \mathrm{cm}^{-1}: 3232(\mathrm{O}-\mathrm{H}), 3084(\mathrm{C}=\mathrm{CH}-\mathrm{Ar}), 3014$ $\left(\mathrm{CH}=\mathrm{CH}_{2}\right), 2936,2829,1634(\mathrm{C}=\mathrm{C}), 1547\left(\mathrm{NO}_{2}\right), 1399$, 
1327, 1260 (C-O), 1127 (C-O), 1066, 999, 912, 764. ${ }^{1} \mathrm{H}$ NMR (400.1 MHz, $\left.\mathrm{CDCl}_{3}\right): \delta 3.35(2 \mathrm{H}, \mathrm{d}, J 6.6 \mathrm{~Hz}$, H1'); 3.93 (3H, s, $\left.\mathrm{OCH}_{3}\right) ; 5.13(2 \mathrm{H}, \mathrm{m}, \mathrm{H} 3$ ') 5.91 (1H, m, H2'); 6.96 (1H, s, H3); 7.50 (1H, d, J 0.9 Hz, H5); 10.67 $(1 \mathrm{H}, \mathrm{s}, \mathrm{OH}) .{ }^{13} \mathrm{C} \mathrm{NMR}\left(100.6 \mathrm{MHz}, \mathrm{CDCl}_{3}\right): \delta 39.4\left(\mathrm{Cl}^{\prime}\right)$; $56.7\left(\mathrm{OCH}_{3}\right) ; 115.1$ (C5); 117.1 (C3'); 118.6 (C3); 131.2 (C4); 133.6 (C6); 135.9 (C2'); 144.9 (C1); 149.8 (C2). HRMS (EI): $m / z$ calcd. for $\mathrm{C}_{10} \mathrm{H}_{11} \mathrm{NO}_{4}[\mathrm{M}]^{+} 209.03$ (100\%): 209.06881, found 209.06921. Compound 3 (yellow oil): IR (film) $v_{\max } / \mathrm{cm}^{-1}: 3471(\mathrm{O}-\mathrm{H}), 3386(\mathrm{O}-\mathrm{H}), 3079(\mathrm{C}=\mathrm{CH}-$ $\mathrm{Ar}), 3018\left(\mathrm{CH}=\mathrm{CH}_{2}\right), 2971,2929,2850,1639(\mathrm{C}=\mathrm{C}), 1542$ $\left(\mathrm{NO}_{2}\right), 1460,1342,1276$ (C-O), 1235, 1117, 1025 (C-O). ${ }^{1} \mathrm{H}$ NMR (400.1 MHz, $\left.\mathrm{CDCl}_{3}\right): \delta 3.32(2 \mathrm{H}, \mathrm{d}, J 6.5 \mathrm{~Hz}$, H1'); 5.19 (2H, m, H3'); 5.90 (2H, m, H2' and $\mathrm{OH}) ; 7.09$ (1H, d, J 1.9 Hz, H6); 7.46 (1H, d, J; 1.8 Hz, H4); 10.5 (1H, s, OH). $\left.{ }^{13} \mathrm{C} \mathrm{NMR} \mathrm{(100.6} \mathrm{MHz,} \mathrm{CDCl}_{3}\right): \delta 39.1\left(\mathrm{Cl}^{\prime}\right)$; 115.0 (C4); 117.1 (C3'); 122.3 (C6); 132.2 (C3); 133.4 (C5); 135.8 (C2’); 141.3 (C2); 146.3 (C1). HRMS (EI): $\mathrm{m} / \mathrm{z}$ calcd. for $\mathrm{C}_{9} \mathrm{H}_{9} \mathrm{NO}_{4}[\mathrm{M}]^{+} 195.03$ (80.6\%): 195.05316, found 195.5241 .

4-Allyl-2-methoxyphenyl acetate (4): To a stirred solution of eugenol $10.00 \mathrm{~g}(6.10 \mathrm{mmol})$ in pyridine $(2.00$ $\mathrm{mL})$ was added dichloromethane $(20 \mathrm{~mL})$ and $10 \mathrm{mg}$ of 4- $N, N$-dimethylaminopyridine (DMAP). The solution was stirred at room temperature for $30 \mathrm{~min}$. Acetic anhydride was added and the reaction was left to continue for $1 \mathrm{~h}$ and after this period, the complete disappearance of the starting product was confirmed by thin layer chromatography (TLC) (AcOEt: $n$-hexane 1:3). To the stopped reaction a $10 \%$ solution of potassium hydrogen sulphate was added and extracted with dichloromethane. The organic phase was washed with water $(3 \times 20 \mathrm{~mL})$ until $\mathrm{pH} 7$, dried with anhydrous $\mathrm{Na}_{2} \mathrm{SO}_{4}$ and vacuum evaporated. Pure product was obtained by column chromatography $(5: 1-3: 1$ AcOEt in hexane), which gave the desired compound with quantitative yield. Compound 4 (oil): IR (film) $v_{\max } / \mathrm{cm}^{-1}$ : 3078 (C=CH-Ar), $3011\left(\mathrm{CH}=\mathrm{CH}_{2}\right), 2971,2935,2843$, $1762(\mathrm{C}=\mathrm{O}), 1634(\mathrm{C}=\mathrm{C}), 1603,1501,1465,1373,1265$ (C-O), 1200, 1143 (C-O), 1030, 917. ${ }^{1} \mathrm{H}$ NMR (400.1 MHz, $\left.\mathrm{CDCl}_{3}\right): \delta 2.31\left(3 \mathrm{H}, \mathrm{s}, \mathrm{CH}_{3} \mathrm{CO}_{2}\right) ; 3.38(2 \mathrm{H}, \mathrm{d}, J 6.7 \mathrm{~Hz}$, $\left.\mathrm{H} 1^{\prime}\right) ; 3.82\left(3 \mathrm{H}, \mathrm{s}, \mathrm{OCH}_{3}\right) ; 5.10(2 \mathrm{H}, \mathrm{m}, \mathrm{H} 3$ ') $5.97(1 \mathrm{H}$, m, H2'); 6.77 (2H, m, H3 and H5); $6.95(1 \mathrm{H}, \mathrm{d}, J 7.9 \mathrm{~Hz}$, H6). ${ }^{13} \mathrm{C} \mathrm{NMR}\left(100.6 \mathrm{MHz}, \mathrm{CDCl}_{3}\right): \delta 20.6\left(\mathrm{CH}_{3} \mathrm{CO}_{2}\right) ; 40.1$ $\left(\mathrm{C}^{\prime}\right.$ '); $55.8\left(\mathrm{OCH}_{3}\right) ; 112.7(\mathrm{C} 3) ; 116.1\left(\mathrm{C}^{\prime}\right) ; 120.6(\mathrm{C} 5)$; 122.5 (C6); 137.0 (C4); 138.0 (C1); 139.0 (C2'); 150.8 (C2); $169.2\left(\mathrm{CH}_{3} \mathrm{CO}_{2}\right)$.

4-Allyl-2-methoxy-3-nitrophenyl acetate (5): To a stirred solution of 4-allyl-2-methoxyphenyl acetate $200 \mathrm{mg}(0.97 \mathrm{mmol})$ in dichloromethane $(5 \mathrm{~mL})$ was carefully added at $0{ }^{\circ} \mathrm{C} 2 \mathrm{~mL}$ of a sulphonitric mixture, which was prepared by adding concentrated nitric acid on concentrated sulphuric acid. The reaction was left to continue for 30 minutes and after this period, the complete disappearance of the starting product was confirmed by thin layer chromatography (TLC) (AcOEt: $n$-hexane 1:3). The reaction was interrupted by adding $15 \mathrm{~mL}$ water. The organic layer was washed with water $(3 \times 20 \mathrm{~mL})$ in order to extract the excess of acid present and dried with anhydrous $\mathrm{Na}_{2} \mathrm{SO}_{4}$, filtered, and the solvent was evaporated at low pressure obtaining an oily product, which was purified by flash chromatography (AcOEt: $n$-hexane) which allowed obtaining $89 \mathrm{mg}(35 \%)$ of the mixture of isomers. The mixture of isomers was, then, re-crystallized from AcOEt $/ n$-hexane mixture. Compound 5 (brown-yellow crystal) $145-147^{\circ} \mathrm{C}$ : IR (KBr) $v_{\max } / \mathrm{cm}^{-1}: 3079$ (C=CH-Ar), $3021\left(\mathrm{CH}=\mathrm{CH}_{2}\right), 2979,2914,2836,1778(\mathrm{C}=\mathrm{O}), 1614$ $(\mathrm{C}=\mathrm{C}), 1527\left(\mathrm{NO}_{2}\right), 1440,1332,1276(\mathrm{C}-\mathrm{O}), 1199(\mathrm{C}-\mathrm{O})$, 1173, 1050, 922. ${ }^{1} \mathrm{H}$ NMR (400.1 $\left.\mathrm{MHz} \mathrm{CDCl}_{3}\right): \delta 2.32$ $\left(3 \mathrm{H}, \mathrm{s}, \mathrm{CH}_{3} \mathrm{CO}_{2}\right) ; 3.76\left(2 \mathrm{H}, \mathrm{d}, J 6.4 \mathrm{~Hz}, \mathrm{H} 1^{\prime}\right) ; 3.91(3 \mathrm{H}, \mathrm{s}$, $\left.\mathrm{OCH}_{3}\right) ; 5.14$ (2H, m, H3'); 5.98 (1H, m, H2'); 6.85 (1H, s, H6); 7.83 (1H, s, H3). $\left.{ }^{13} \mathrm{C} \mathrm{NMR} \mathrm{(100.6} \mathrm{MHz,} \mathrm{CDCl}_{3}\right)$ : $\delta 20.4\left(\underline{\mathrm{CH}}_{3} \mathrm{CO}_{2}\right) ; 37.7\left(\mathrm{C}^{\prime}\right.$ '); $56.3\left(\mathrm{OCH}_{3}\right) ; 114.2$ (C6); 117.4 (C3'); 120.7 (C3); 134.8 (C4); 136.1 (C2'); 137.7 (C5); 140.9 (C1); 155.1 (C2); $168.4\left(\mathrm{CH}_{3} \mathrm{CO}_{2}\right)$. HRMS (EI): $m / z$ calcd. for $\mathrm{C}_{12} \mathrm{H}_{13} \mathrm{NO}_{5}[\mathrm{M}]^{+} 251.05$ (9.2\%): 251.07937, found 251.07273.

(E)-2-Methoxy-4-(prop-1-enyl) phenol (isoeugenol 6): To $8.0 \mathrm{~g}$ of ethyleneglicol placed in a three-neck roundbottom flask of $100 \mathrm{~mL}$ are added $7.90 \mathrm{~g}$ of $\mathrm{KOH}(134$ mmol), and submerged in a sand bath. To the mixture eugenol $5.0 \mathrm{~g}(30.5 \mathrm{mmol})$ is added and the system is refluxed at $160{ }^{\circ} \mathrm{C}$ for about approximately 5 hours; at this time the reaction is stopped. The excess of $\mathrm{KOH}$ is neutralized with $25 \mathrm{~mL}$ of a $6 \mathrm{~mol} \mathrm{~L}^{-1}$ hydrochloric acid solution, the mixture is extracted with $\mathrm{CHCl}_{3}$ $(2 \times 50 \mathrm{~mL})$ and the organic phase is dried with anhydrous $\mathrm{Na}_{2} \mathrm{SO}_{4}$ and the solvent evaporated under vacuum. After chromatographic column purification, $4.25 \mathrm{~g}$ of a brown oil was obtained (85\%). IR (film) $v_{\max } / \mathrm{cm}^{-1}: 3503(\mathrm{O}-\mathrm{H})$, 3057 (C=CH-Ar), 3014 (CH=CH), 2936, 2930, 2843, 1603, 1506, 1367, 1030, 963. ${ }^{1} \mathrm{H} \mathrm{NMR}\left(400.1 \mathrm{MHz}, \mathrm{CDCl}_{3}\right): \delta$ $1.86\left(3 \mathrm{H}, \mathrm{dd}, J 1.5\right.$ and $\left.6.6 \mathrm{~Hz}, \mathrm{CH}_{3}\right) ; 3.90\left(3 \mathrm{H}, \mathrm{s}, \mathrm{OCH}_{3}\right)$; $5.55(1 \mathrm{H}, \mathrm{s}, \mathrm{OH}) ; 6.08\left(1 \mathrm{H}, \mathrm{dq}, J 6.6\right.$ and $\left.15.7 \mathrm{~Hz}, \mathrm{H} 2{ }^{\prime}\right)$; $6.32\left(1 \mathrm{H}, \mathrm{dd}, J 1.5\right.$ and $\left.15.7 \mathrm{~Hz}, \mathrm{H} 1^{\prime}\right)$; 6.85 (3H, m, H3, H5 and H6). ${ }^{13} \mathrm{C} \mathrm{NMR}\left(100.6 \mathrm{MHz}, \mathrm{CDCl}_{3}\right): \delta 18.3\left(\mathrm{CH}_{3}\right) ; 55.8$ $\left(\mathrm{OCH}_{3}\right) ; 107.8(\mathrm{C} 5) ; 114.3(\mathrm{C} 6) ; 119.3$ (C3); 123.4 (C4); 130.6 (C2); 130.7 (C1); 144.7 (C2'); 146.5 (C1').

\section{Biological}

3-(4,5-Dimethylthiazol-2-yl)-2,5-diphenyl-tetrazolium bromide (MTT) and reduced nicotinamide adenine 
dinucleotide (NADH) were obtained from Sigma Aldrich Co (St. Louis, USA). All other chemicals were purchased from GIBCO BRL Life Technologies (Grand Island, NY, USA).

\section{Study on human tumor cell lines}

\section{Cell culture and treatments}

The experimental cell cultures were obtained from American Type Culture Collection (Rockville, MD, USA). DU-145 cells (androgen-insensitive prostate cancer cells) were grown in Dulbecco's modified Eagle's medium (DMEM) containing 10\% FCS, $100 \mathrm{U} \mathrm{mL}^{-1}$ penicillin, $100 \mu \mathrm{g} \mathrm{mL}^{-1}$ streptomycin, $1 \mathrm{mM}$ glutamine, and $1 \%$ non essential amino-acids. KB cells (oral squamous carcinoma cells) were maintained in RPMI supplemented with $10 \%$ fetal calf serum (FCS), $100 \mathrm{U} \mathrm{ml}^{-1}$ penicillin, and $100 \mu \mathrm{g}$ $\mathrm{mL}^{-1}$ streptomycin. After $24 \mathrm{~h}$ incubation at $37^{\circ} \mathrm{C}$ under a humidified $5 \%$ carbon dioxide to allow cell attachment, the cells were treated with different concentrations of eugenol (1) and its synthetic analogues (2-6) and incubated for $72 \mathrm{~h}$ under the same conditions. Stock solution of compounds were prepared in DMSO and the final concentration of this solvent was kept constant at $0.25 \%$. Control cultures received DMSO alone.

\section{MTT bioassay}

MTT assay was performed as previously described. ${ }^{13}$ Briefly, the cells were set up $6 \times 10^{3}$ cells per well of a 96-well, flat-bottomed $200 \mu \mathrm{L}$ microplate. Cells were incubated at $37^{\circ} \mathrm{C}$ in a humidified $5 \% \mathrm{CO}_{2} / 95 \%$ air mixture and treated with doxorubicin, used as a positive control, and the compounds (1-6) at different concentrations for 72 hours. Four hours before the end of the treatment time, $20 \mu \mathrm{L}$ of 0.5\% 3-(4, 5-dimethyl-thiazol-2-yl)-2,5-diphenyl-tetrazolium bromide (MTT) in phosphate buffer saline (PBS) were added to each microwell. Cells were washed once before adding MTT. After $4 \mathrm{~h}$ of incubation at $37^{\circ} \mathrm{C}$, the supernatant was removed and replaced with $100 \mu \mathrm{L}$ of DMSO. The optical density of each well sample was measured with a microplate spectrophotometer reader (Digital and Analog Systems, Rome, Italy) at $\lambda=550 \mathrm{~nm}$.

\section{Lactic dehydrogenase $(\mathrm{LDH})$ release}

Lactic dehydrogenase (LDH) activity was spectrophotometrically measured in the culture medium and in the cellular lysates at $\lambda=340 \mathrm{~nm}$ by analyzing NADH reduction during the pyruvate-lactate transformation, as previously reported. ${ }^{14}$ Cells were lysed with $50 \mathrm{mmol} \mathrm{L}^{-1}$ Tris- $\mathrm{HCl}+20$ mmol L ${ }^{-1}$ EDTA pH $7.4+0.5 \%$ sodium dodecyl sulfate (SDS), further disrupted by sonication and centrifuged at $13.000 \mathrm{~g}$ for $15 \mathrm{~min}$. The assay mixture $(1 \mathrm{~mL}$ final volume) for the enzymatic analysis contained: $33 \mu \mathrm{L}$ of sample (5-10 $\mu \mathrm{g}$ of protein) in $48 \mathrm{mmol} \mathrm{L}^{-1} \mathrm{PBS} \mathrm{pH} 7.5$ plus $1 \mathrm{mmol} \mathrm{L}^{-1}$ pyruvate and $0.2 \mathrm{mmol} \mathrm{L}^{-1} \mathrm{NADH}$. The percentage of $\mathrm{LDH}$ released was calculated as percentage of the total amount, considered as the sum of the enzymatic activity present in the cellular lysate and that in the culture medium. A Hitachi U-2000 spectrophotometer (Hitachi, Tokyo, Japan) was used.

\section{Statistical Analysis}

Statistical analysis of results was performed by using one-way ANOVA followed by Dunnett's post-hoc test for multiple comparisons with control. All statistical analyses were performed using the statistical software package SYSTAT, version 9 (Systat Inc., Evanston IL, USA).

We included after the reference section some supplementary information. This incorporated the 1D and 2D NMR, HRMS and IR spectra. Finally we indicated the solvent utilized in each case and all relevant information for these compounds.

\section{Results and Discussion}

Cancer is the largest single cause of death in both men and women. Recently, resistance to anticancer drugs has been observed. Therefore, the research and development of more effective and less toxic drugs by the pharmaceutical industry has become necessary. Many substances derived from dietary or medicinal plants are known to be effective and versatile chemopreventive and antitumoral agents in a number of experimental models of carcinogenesis. There is increasing evidence for an association between a high consumption of fruit and vegetables and the reduced risk of oral cancer and prostate carcinoma, the most common tumor in men. ${ }^{7,8}$ Since antiproliferative screening models in vitro provide important preliminary data to help selecting compounds with potential antineoplastic properties for future study, eugenol (1) and its analogues (2-6) were tested in vitro for their potential human tumor cell growth inhibitory effect on DU-145 and KB tumor cell lines using MTT assay, a non-radioactive, fast and economical assay widely used to quantify cell viability and proliferation. MTT is a yellow water-soluble tetrazolium salt. Metabolically active cells are able to convert the dye to water-insoluble dark blue formazan by reductive cleavage of the tetrazolium ring. The results, summarized in Table 1, show that eugenol (1) and its analogues (2-6) exhibited a inhibitory effect on both the human cancer cells examined, with $\mathrm{IC}_{50}$ value lower than of $50 \times 10^{-6} \mathrm{~mol} \mathrm{~L}^{-1}$. The compounds 2,4 and $\mathbf{6}$ showed cell growth inhibition activity comparable to that of eugenol, while the compounds 5-allyl-3-nitrobenzene- 
Table 1. Cell growth inhibition, assayed using MTT test, of DU-145 and $\mathrm{KB}$ cells untreated and treated with eugenol (1) and its analogues (2-6) at different concentrations for 72 hours. Stock solution of compounds was prepared in DMSO and the final concentration of this solvent was kept constant at $0.25 \%$. Control cultures received DMSO alone

\begin{tabular}{|c|c|c|c|}
\hline Treatments & DU-145 cells & $I C_{50}\left(\mathrm{~mol} \mathrm{~L}^{-1}\right)^{a}$ & $\mathrm{~KB}$ cells \\
\hline 1 & $30.39 \times 10^{-6}$ & & $28.48 \times 10^{-6}$ \\
\hline 2 & $34.98 \times 10^{-6}$ & & $33.97 \times 10^{-6}$ \\
\hline 3 & $19.02 \times 10^{-6 *}$ & & $18.11 \times 10^{-6 *}$ \\
\hline 4 & $29.26 \times 10^{-6}$ & & $29.68 \times 10^{-6}$ \\
\hline 5 & $21.50 \times 10^{-6 *}$ & & $21.26 \times 10^{-6 *}$ \\
\hline 6 & $30.71 \times 10^{-6}$ & & $27.50 \times 10^{-6}$ \\
\hline Dox & $9.28 \times 10^{-6}$ & & $1.35 \times 10^{-6}$ \\
\hline
\end{tabular}

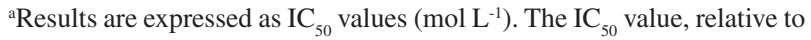
untreated control, represents the concentration that inhibited cell viability by $50 \%$. Doxorubicin (Dox) was used as a positive control. Values are the mean \pm SD of three experiments performed in triplicate. *significant vs. eugenol (1) treated cells $(\mathrm{p}<0.001)$.

1,2-diol (3) and 4-allyl-2-methoxy-5-nitrophenyl acetate (5) were significantly $(\mathrm{p}<0,001)$ more active than eugenol, with $\mathrm{IC}_{50}$ value in DU-145 cells of $19.02 \times 10^{-6} \mathrm{~mol} \mathrm{~L}^{-1}$ and $21.5 \times 10^{-6} \mathrm{~mol} \mathrm{~L}^{-1}$, respectively, and in $\mathrm{KB}$ cells of 18.11 $\times 10^{-6} \mathrm{~mol} \mathrm{~L}^{-1}$ and $21.26 \times 10^{-6} \mathrm{~mol} \mathrm{~L}^{-1}$, respectively. The reason for this increased potency with nitration reaction may be due to increased lipophilicity which allows more compound to cross the plasma membrane of the cell. Also the position of nitro group could play a key role, in fact the 4-allyl-2-methoxy-5-nitrophenyl acetate (5) was more active than 4-allyl-2-methoxy-6-nitrophenol (2). It has been suggested that available hydroxyl groups are important for decreasing cancer cell viability. ${ }^{9}$ Our results seem to agree to this hypothesis, in fact the compound 5-allyl-3nitrobenzene-1,2-diol (3) was significantly more potent than eugenol (1).

Necrosis results in a disruption of cytoplasmic membrane and the necrotic cells release cytoplasmic LDH and other cytotoxic substances into the medium. We therefore examined the membrane permeability of the treated cells through the existence of LDH in their culture medium. Our results seem to suggest that apoptotic cell demise appears to be induced in KB and DU-145 cells. In fact, no statistically significant increase in LDH release was observed in our experimental conditions (Table 2).

\section{Conclusion}

In summary, these results are starting point for further investigations, seem to indicate that a apoptotic process could be activated by eugenol and its analogues in our experimental conditions, and that the presence of nitro and hydroxyl groups could be positively correlated with the potency of 5-allyl-3-nitrobenzene-1,2-diol (3) and
Table 2. Lactate dehydrogenase (LDH) release) in DU-145 and KB cells untreated and treated with eugenol (1) and its analogues (2-6) at different concentrations for 72 hours. Stock solution of compounds was prepared in DMSO and the final concentration of this solvent was kept constant at $0.25 \%$. Control cultures received DMSO alone.

\begin{tabular}{|c|c|c|c|}
\hline Treatments & DU-145 cells & $\%$ LDH released & $\mathrm{KB}$ cells \\
\hline Control & $2.9 \pm 0.7$ & & $4.9 \pm 0.6$ \\
\hline \multicolumn{4}{|l|}{1} \\
\hline $12 \times 10-6 \mathrm{~mol} \mathrm{~L}^{-1}$ & $3.1 \pm 0.1$ & & $3.6 \pm 0.4$ \\
\hline $25 \times 10-6 \mathrm{~mol} \mathrm{~L}^{-1}$ & $4.3 \pm 0.9$ & & $4.3 \pm 0.6$ \\
\hline $50 \times 10-6 \mathrm{~mol} \mathrm{~L}^{-1}$ & $3.5 \pm 0.3$ & & $2.9 \pm 0.9$ \\
\hline \multicolumn{4}{|l|}{2} \\
\hline $12 \times 10-6 \mathrm{~mol} \mathrm{~L}^{-1}$ & $3.3 \pm 0.9$ & & $4.5 \pm 0.8$ \\
\hline $25 \times 10-6 \mathrm{~mol} \mathrm{~L}^{-1}$ & $4.3 \pm 0.8$ & & $3.7 \pm 0.4$ \\
\hline $50 \times 10-6 \mathrm{~mol} \mathrm{~L}^{-1}$ & $3.8 \pm 0.9$ & & $2.9 \pm 0.3$ \\
\hline \multicolumn{4}{|l|}{3} \\
\hline $12 \times 10-6 \mathrm{~mol} \mathrm{~L}^{-1}$ & $4.6 \pm 0.7$ & & $4.5 \pm 0.6$ \\
\hline $25 \times 10-6 \mathrm{~mol} \mathrm{~L}^{-1}$ & $3.4 \pm 0.9$ & & $2.4 \pm 0.9$ \\
\hline $50 \times 10-6 \mathrm{~mol} \mathrm{~L}^{-1}$ & $2.8 \pm 0.9$ & & $4.4 \pm 0.9$ \\
\hline \multicolumn{4}{|l|}{4} \\
\hline $12 \times 10-6 \mathrm{~mol} \mathrm{~L}^{-1}$ & $2.6 \pm 0.7$ & & $3.9 \pm 0.5$ \\
\hline $25 \times 10-6 \mathrm{~mol} \mathrm{~L}^{-1}$ & $3.1 \pm 0.9$ & & $2.7 \pm 0.8$ \\
\hline $50 \times 10-6 \mathrm{~mol} \mathrm{~L}^{-1}$ & $2.9 \pm 0.3$ & & $3.4 \pm 0.2$ \\
\hline \multicolumn{4}{|l|}{5} \\
\hline $12 \times 10-6 \mathrm{~mol} \mathrm{~L}^{-1}$ & $3.7 \pm 0.5$ & & $4.0 \pm 0.5$ \\
\hline $25 \times 10-6 \mathrm{~mol} \mathrm{~L}^{-1}$ & $4.4 \pm 0,9$ & & $3.7 \pm 0,6$ \\
\hline $50 \times 10-6 \mathrm{~mol} \mathrm{~L}^{-1}$ & $3.9 \pm 0.3$ & & $2.4 \pm 0.9$ \\
\hline \multicolumn{4}{|l|}{6} \\
\hline $12 \times 10-6 \mathrm{~mol} \mathrm{~L}^{-1}$ & $3.7 \pm 0.5$ & & $3.9 \pm 0.8$ \\
\hline $25 \times 10-6 \mathrm{~mol} \mathrm{~L}^{-1}$ & $3.0 \pm 0.9$ & & $3.5 \pm 0.6$ \\
\hline $50 \times 10-6 \mathrm{~mol} \mathrm{~L}^{-1}$ & $3.9 \pm 0.2$ & & $3.6 \pm 0.5$ \\
\hline
\end{tabular}

The results are expressed as percentage of LDH released into the cell medium with respect to total $\mathrm{LDH}$. Each value represents the mean \pm $\mathrm{SD}$ of three experiments, performed in triplicate.

4-allyl-2-methoxy-5-nitrophenyl acetate (5) compounds, suggesting that these nitro-derivatives may have a chemotherapeutic role in the future.

\section{Acknowledgments}

The authors thank Andrés Bello University (grant DIUNAB 13-04) and University T. F. Santa Maria (grant DGIP $\mathrm{N}^{\mathrm{o}}$ 13.06.26) for financial support. We also wish to thank Dr. Víctor Cárdenas for his valuable contribution in the elaboration of this work. We also wish to thank MECESUP (grant UCH 0116) de la Red Nacional de Doctorado en Química, for HRMS analysis.

\section{Supplementary Information}

Suplementary data are available free of charge at http://jbcs.sbq.org.br, as PDF file. 


\section{References}

1. Ghosh, R.; Nadiminty, N.; Fitzpatrick, J. E.; Alworth, W. L.; Slaga, T. J.; Kumar, A. P.; J. Biol. Chem. 2005, 280, 5812.

2. Tiku, A. B.; Abraham, S. K.; Kale, R. K.; J. Radiat. Res. 2004, $45,435$.

3. Mihara, S.; Shibamoto, T.; J. Agric. Food Chem. 1982, 30, 1215.

4. Park, I. K.; Lee, H. S.; Lee, S. G.; Park, J. D.; Ahn, Y. J.; J. Agric. Food Chem. 2000, 48, 2528.

5. Ogata, M.; Hoshi, M.; Urano, S.; Endo, T.; Chem. Pharm. Bull. 2000, 481467.

6. Yoo, C. B.; Han, K. T.; Cho, K. S.; Ha, J.; Park, H. J.; Nam, J. H.; Kil, U. H.; Lee, K. T.; Cancer Lett. 2005, 225, 41.

7. Morse, D. E.; Pendrys, D. G.; Katz, R. V.; Holford, T. R.; Krutchkoff, D. J.; Eisenberg, E.; Kosis D. L.; Kerpel, S.; Freedman, P., Mayne, S. T.; Cancer Causes Control 2000, 11, 713.
8. Thompson, I. M.; Coltman Jr., C. A.; Crowley, J.; Prostate 1997, $33,217$.

9. Morris, G. Z.; Williams, R. L.; Elliott, M. S.; Beebe, S. J.; Prostate 2002, 52, 319

10. Ntamila, M. S.; Hassanali, A.; J. Chem. Educ. 1976, 53, 263.

11. Carrasco, H.; Espinoza, L.; Gallardo, C.; Cardona, W.; Ibáñez, L.; Álvarez, L.; Acta Crystallographica Section E 2006, E62, 01782.

12. Keevil, T.; Peterson, T.; Bryan, J.; J. Chem. Ed. 1993, 4, A96.

13. Cardile, V.; Renis, M.; Scifo, C.; Lombardo, L.; Gulino, R.; Mancari, B.; Panico, A.; Int. J. Biochem. Cell Biol. 2004, 36, 849.

14. Russo, A.; Cardile, V.; Lombardo, L.; Vanella, L.; Vanella, A.; Garbarino, J. A.; J. Ethnopharmacol. 2005, 100, 323.

Received: July 19, 2007 Web Release Date: March 13, 2008 


\title{
Eugenol and its Synthetic Analogues Inhibit Cell Growth of Human Cancer Cells (Part I)
}

\author{
H. Carrasco A., ${ }^{*}, a$ L. Espinoza C., ${ }^{b}$ V. Cardile, ${ }^{c}$ C. Gallardo, ${ }^{b}$ W. Cardona, ${ }^{a}$ \\ L. Lombardo, ${ }^{c}$ K. Catalán M., ${ }^{b}$ M. Cuellar F. ${ }^{e}$ and A. Russo ${ }^{d}$
}

\author{
${ }^{a}$ Departamento de Ciencias Químicas, Universidad Andrés Bello, Campus Viña del Mar, Viña del Mar, Chile \\ ${ }^{b}$ Departamento de Química, Universidad Técnica Federico. Santa Maria, Av. España $N^{\circ} 1680$, \\ Valparaiso, Chile \\ ${ }^{c}$ Department of Physiological Sciences, University of Catania, V.le A. Doria 6, 95125, Catania, Italy \\ ${ }^{d}$ Department of Biological Chemistry, Medical Chemistry and Molecular Biology, University of Catania, \\ V.le A. Doria 6, 95125, Catania, Italy \\ ${ }^{e}$ Facultad de Farmacia, Universidad de Valparaíso, Av. Gran Bretaña $N^{\circ} 1093$, Valparaíso, Chile
}

\begin{abstract}
4-Allyl-2- methoxy-6-nitrophenol: In the pages S2-S4 we indicated the 1D \& 2D NMR, HRMS, and IR spectra. IR spectra were recorded as thin film or $\mathrm{KBr}$ pellets in a Nicolet Impact 420 spectrometer. $v_{\max }$ values are expressed in $\mathrm{cm}^{-1} .{ }^{1} \mathrm{H}$ and ${ }^{13} \mathrm{C}$ NMR spectra were recorded in $\mathrm{CDCl}_{3}$ solutions and referenced to the residual peak of $\mathrm{CHCl}_{3}$ at $\delta$ 7.26 ppm and $\delta 77.00$ ppm for ${ }^{1} \mathrm{H}$ and ${ }^{13} \mathrm{C}$, respectively, on a Bruker Avance 400 Digital NMR spectrometer, operating at $400.1 \mathrm{MHz}$ for ${ }^{1} \mathrm{H}$ and $100.6 \mathrm{MHz}$ for ${ }^{13} \mathrm{C}$. Chemical shifts are reported in $\delta \mathrm{ppm}$ and coupling constants $(J)$ are given in Hz. HRMS were recorder on a MAT 95XP, Thermo Finnigan spectrometer and represented at $\mathrm{m} / \mathrm{z}$ (\% rel. int.).
\end{abstract}

5-Allyl-3-nitrobenzene-1,2-diol: In the pages S5-S7 we indicated the 1D \& 2D NMR, HRMS, and IR spectra. IR spectra were recorded as thin film or $\mathrm{KBr}$ pellets in a Nicolet Impact 420 spectrometer. $v_{\text {max }}$ values are expressed in $\mathrm{cm}^{-1} .{ }^{1} \mathrm{H}$ and ${ }^{13} \mathrm{C}$ NMR spectra were recorded in $\mathrm{CDCl}_{3}$ solutions and referenced to the residual peak of $\mathrm{CHCl}_{3}$ at $\delta$ $7.26 \mathrm{ppm}$ and $\delta 77.00 \mathrm{ppm}$ for ${ }^{1} \mathrm{H}$ and ${ }^{13} \mathrm{C}$, respectively, on a Bruker Avance 400 Digital NMR spectrometer, operating at $400.1 \mathrm{MHz}$ for ${ }^{1} \mathrm{H}$ and $100.6 \mathrm{MHz}$ for ${ }^{13} \mathrm{C}$. Chemical shifts are reported in $\delta$ ppm and coupling constants $(J)$ are given in Hz. HRMS were recorder on a MAT 95XP, Thermo Finnigan spectrometer and represented at $\mathrm{m} / \mathrm{z}$ (\% rel. int.).

4-Allyl-2-methoxyphenyl acetate: In the pages S8-S9 we indicated the $1 \mathrm{D} \& 2 \mathrm{D}$ NMR, HRMS, and IR spectra.

*e-mail: hcarrasco@unab.cl
IR spectra were recorded as thin film or $\mathrm{KBr}$ pellets in a Nicolet Impact 420 spectrometer. $v_{\max }$ values are expressed in $\mathrm{cm}^{-1} .{ }^{1} \mathrm{H}$ and ${ }^{13} \mathrm{C}$ NMR spectra were recorded in $\mathrm{CDCl}_{3}$ solutions and referenced to the residual peak of $\mathrm{CHCl}_{3}$ at $\delta$ $7.26 \mathrm{ppm}$ and $\delta 77.00 \mathrm{ppm}$ for ${ }^{1} \mathrm{H}$ and ${ }^{13} \mathrm{C}$, respectively, on a Bruker Avance 400 Digital NMR spectrometer, operating at $400.1 \mathrm{MHz}$ for ${ }^{1} \mathrm{H}$ and $100.6 \mathrm{MHz}$ for ${ }^{13} \mathrm{C}$. Chemical shifts are reported in $\delta$ ppm and coupling constants $(J)$ are given in Hz. HRMS were recorder on a MAT 95XP, Thermo Finnigan spectrometer and represented at $\mathrm{m} / \mathrm{z}$ (\% rel. int.).

4-Allyl-2-methoxy-5-nitrophenyl acetate: In the pages S10-S11 we indicated the 1D \& 2D NMR, HRMS, and IR spectra. IR spectra were recorded as thin film or $\mathrm{KBr}$ pellets in a Nicolet Impact 420 spectrometer. $v_{\max }$ values are expressed in $\mathrm{cm}^{-1} .{ }^{1} \mathrm{H}$ and ${ }^{13} \mathrm{C}$ NMR spectra were recorded in $\mathrm{CDCl}_{3}$ solutions and referenced to the residual peak of $\mathrm{CHCl}_{3}$ at $\delta 7.26 \mathrm{ppm}$ and $\delta 77.00 \mathrm{ppm}$ for ${ }^{1} \mathrm{H}$ and ${ }^{13} \mathrm{C}$, respectively, on a Bruker Avance 400 Digital NMR spectrometer, operating at $400.1 \mathrm{MHz}$ for ${ }^{1} \mathrm{H}$ and 100.6 MHz for ${ }^{13} \mathrm{C}$. Chemical shifts are reported in $\delta \mathrm{ppm}$ and coupling constants $(J)$ are given in Hz. HRMS were recorder on a MAT 95XP, Thermo Finnigan spectrometer and represented at $m / z$ (\% rel. int.).

(E)-2-Methoxy-4-(prop-1-enyl) phenol: In the pages S12-S13 we indicated the 1D \& 2D NMR, HRMS, and IR spectra. IR spectra were recorded as thin film or $\mathrm{KBr}$ pellets in a Nicolet Impact 420 spectrometer. $v_{\max }$ values are expressed in $\mathrm{cm}^{-1} .{ }^{1} \mathrm{H}$ and ${ }^{13} \mathrm{C}$ NMR spectra were recorded in $\mathrm{CDCl}_{3}$ solutions and referenced to the 
residual peak of $\mathrm{CHCl}_{3}$ at $\delta 7.26 \mathrm{ppm}$ and $\delta 77.00 \mathrm{ppm}$ for ${ }^{1} \mathrm{H}$ and ${ }^{13} \mathrm{C}$, respectively, on a Bruker Avance 400 Digital NMR spectrometer, operating at $400.1 \mathrm{MHz}$ for ${ }^{1} \mathrm{H}$ and 100.6 MHz for ${ }^{13} \mathrm{C}$. Chemical shifts are reported in $\delta \mathrm{ppm}$ and coupling constants $(J)$ are given in Hz. HRMS were recorder on a MAT 95XP, Thermo Finnigan spectrometer and represented at $m / z$ (\% rel. int.).
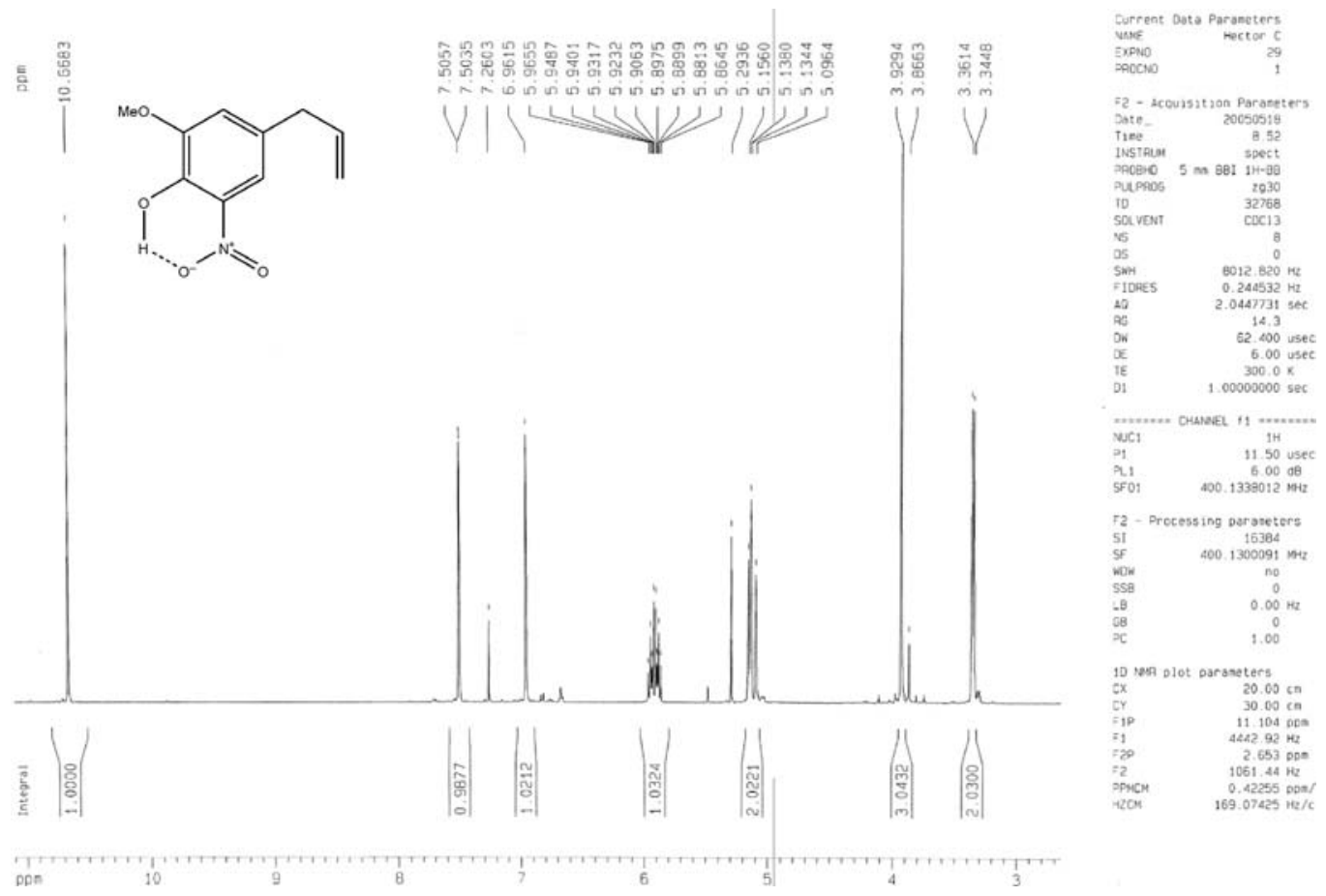

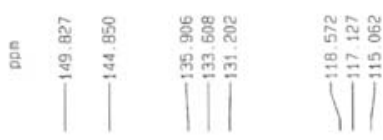<smiles>C=CCc1cc(O)c(O)c(O)c1</smiles>

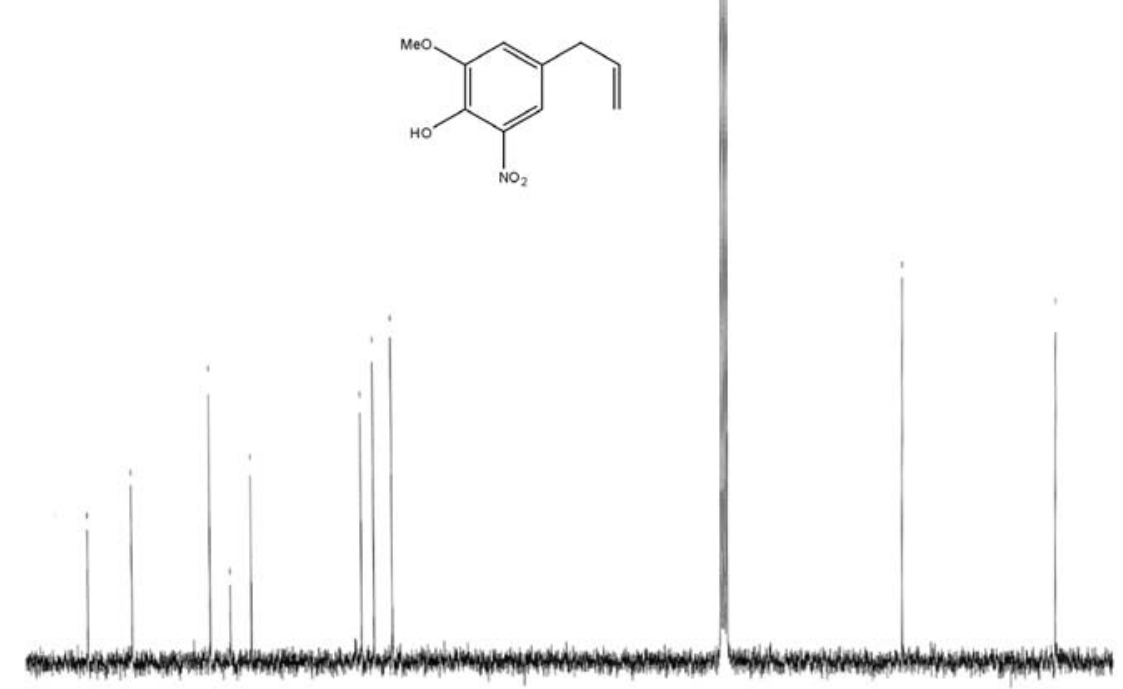

Don

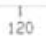

${ }_{100}^{1}$

Bo

$\frac{1}{60}$
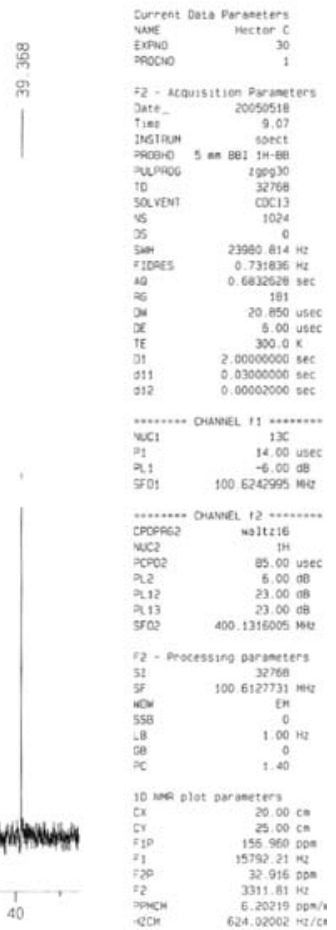

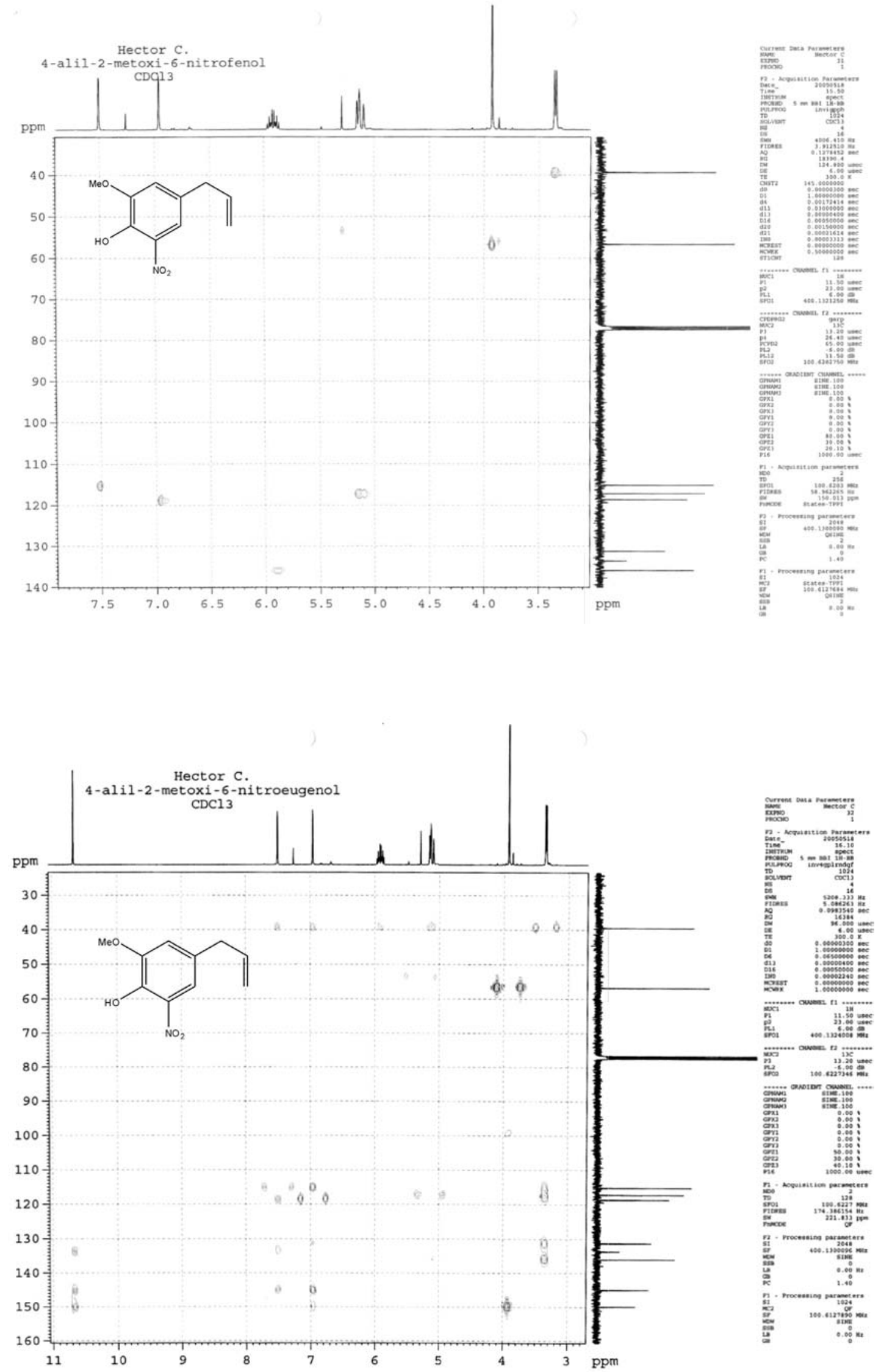
Muestra Nitroeugenol (01)<smiles>C=CCc1cc(OC)c(O)c([N+](=O)[O-])c1</smiles>
$\mathrm{C}_{10} \mathrm{H}_{11} \mathrm{NO}_{4}$

Exact Mass: 209.06881

Mol. Wt.: 209.19868

C, $57.41 ; \mathrm{H}, 5.30 ; \mathrm{N}, 6.70 ; \mathrm{O}, 30.59$

Espectro impacto por electrones
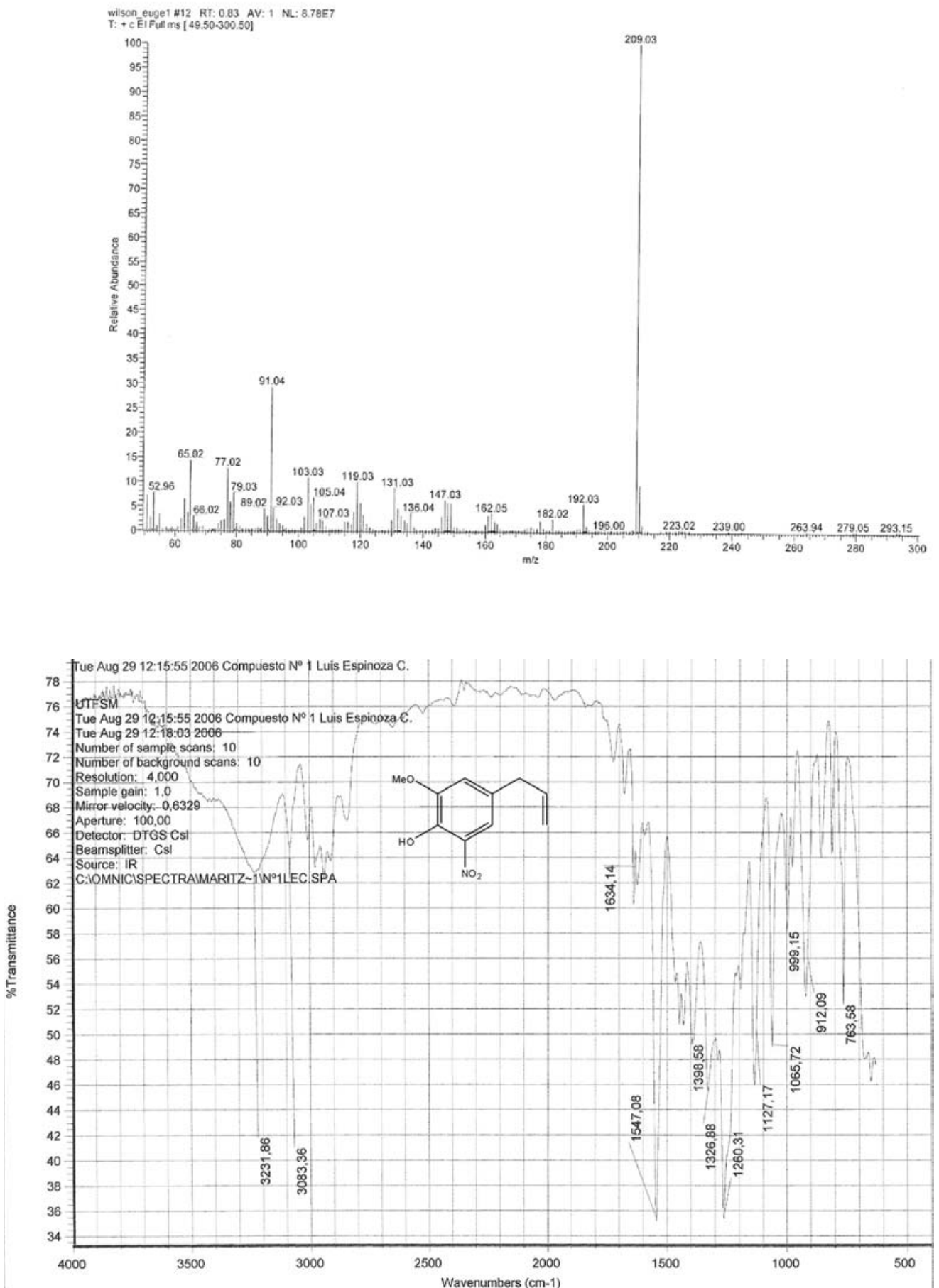

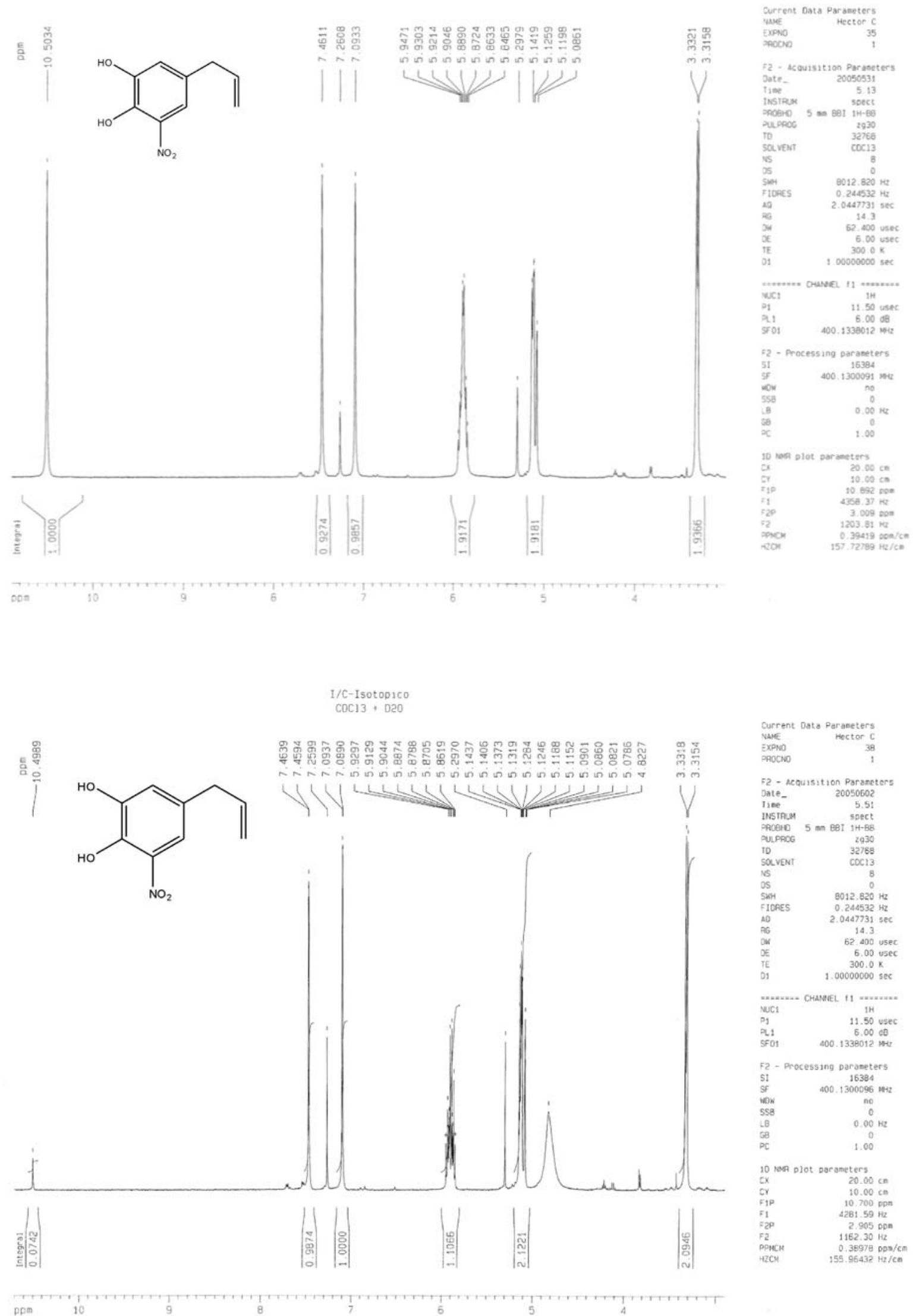

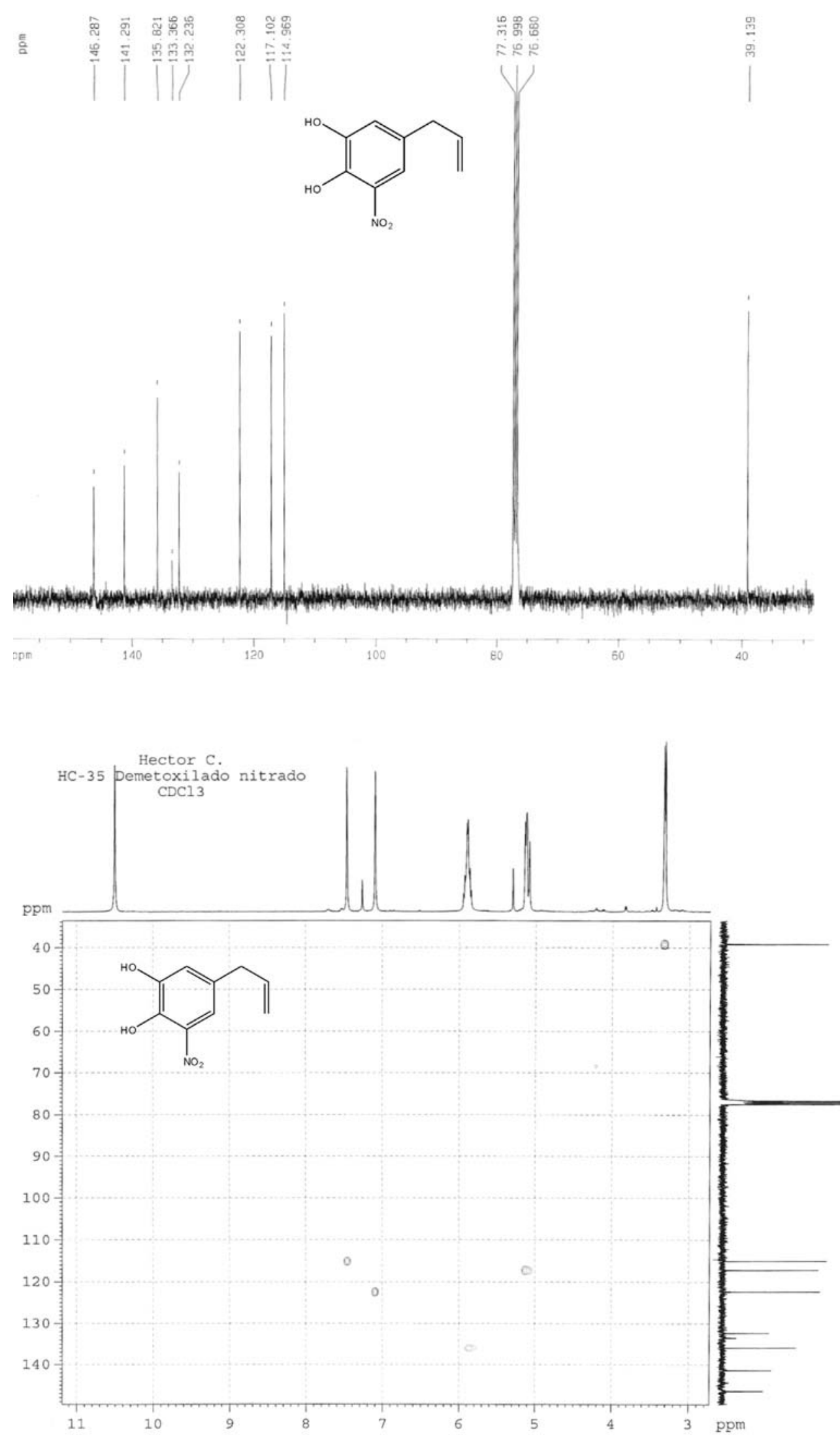
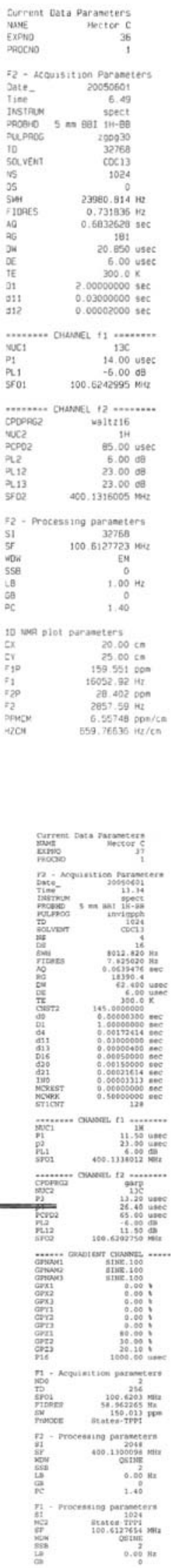
<smiles>C=CCc1cc(O)c(O)c([N+](=O)[O-])c1</smiles>

Exact Mass: 195.05316

Mol. Wt.: 195.17210

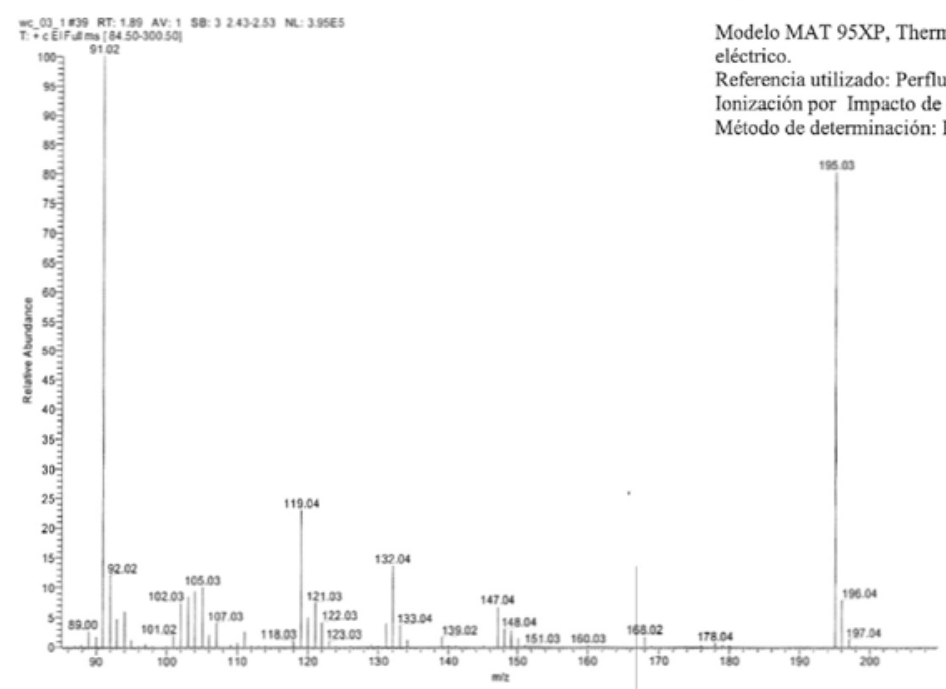

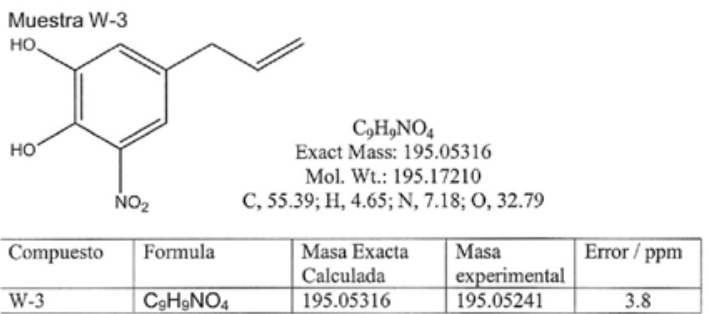

Especificaciones del espectrómetro de masas:

Modelo MAT 95XP, Thermo Finnigan. Analizador de doble enfoque, sector magnético y

( 2 C43).

Ionización por Impacto de electrones, EI.

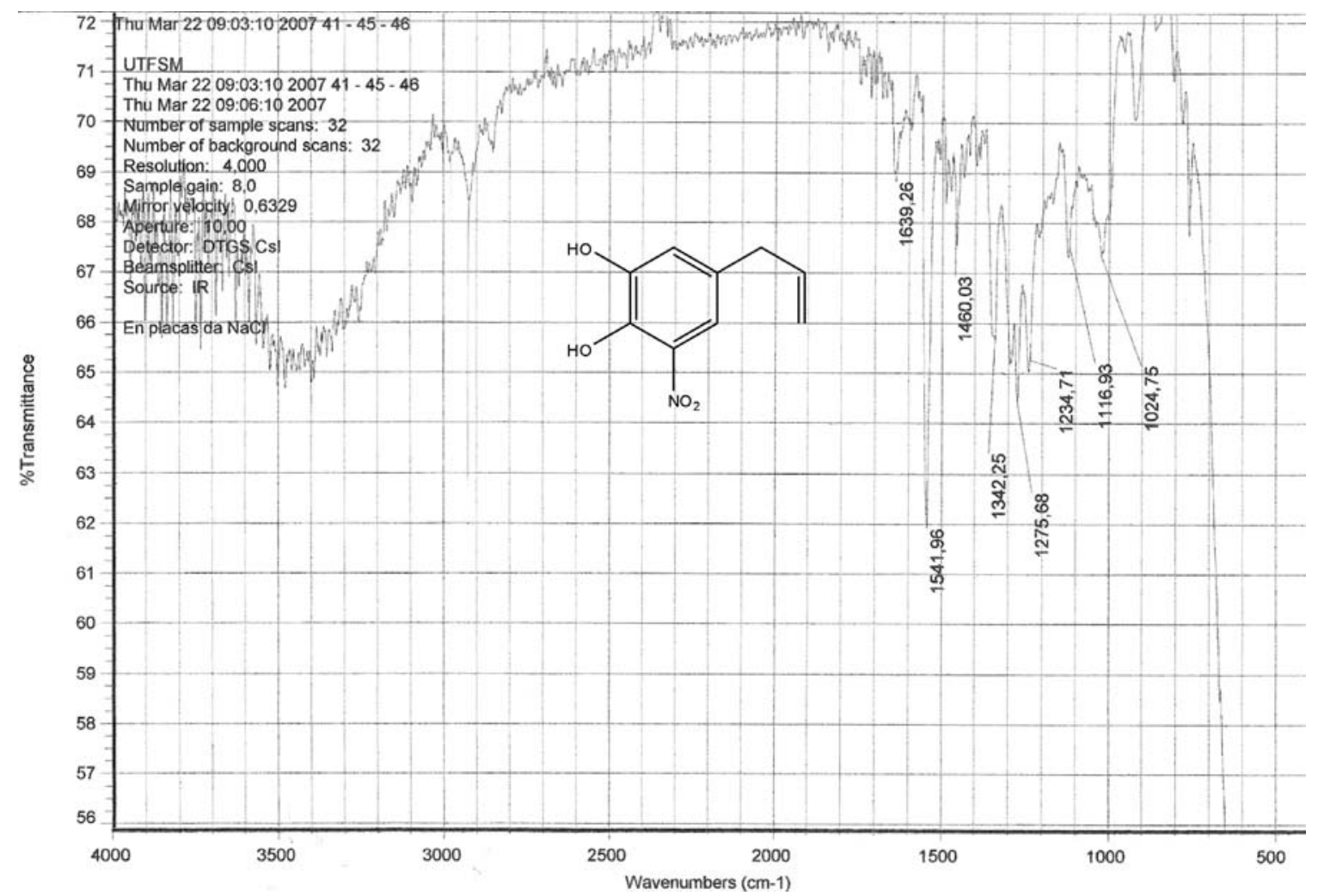



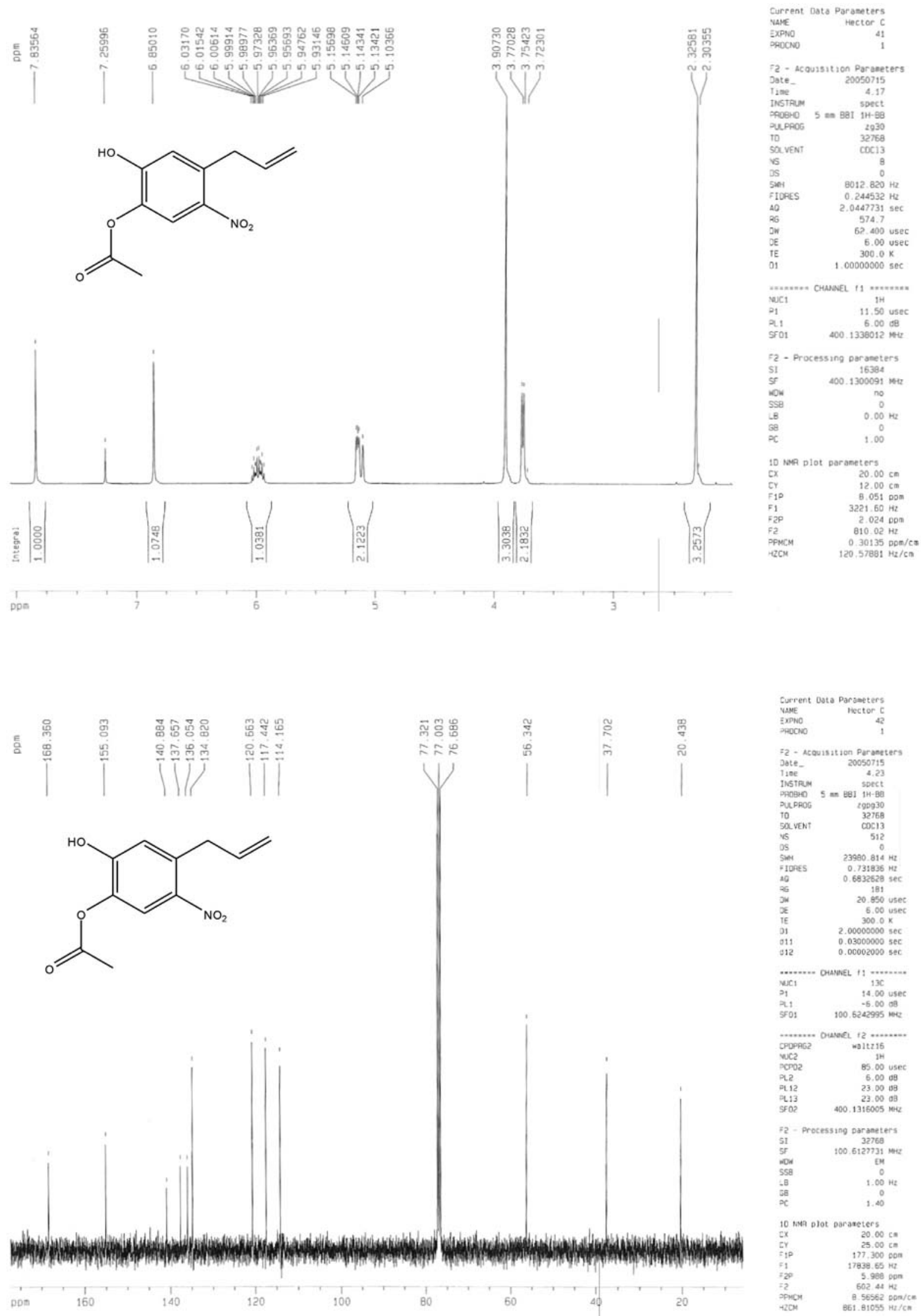

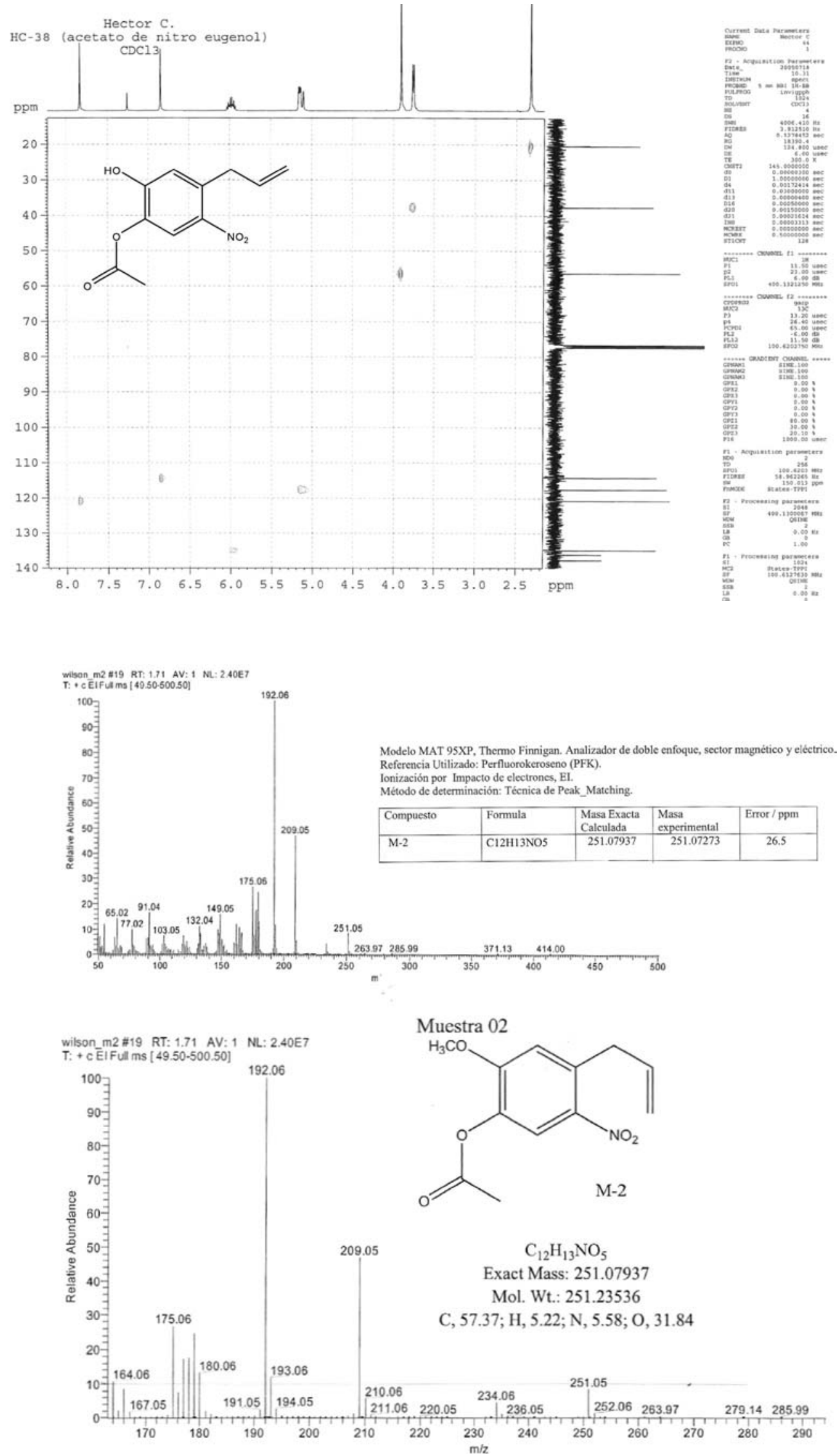

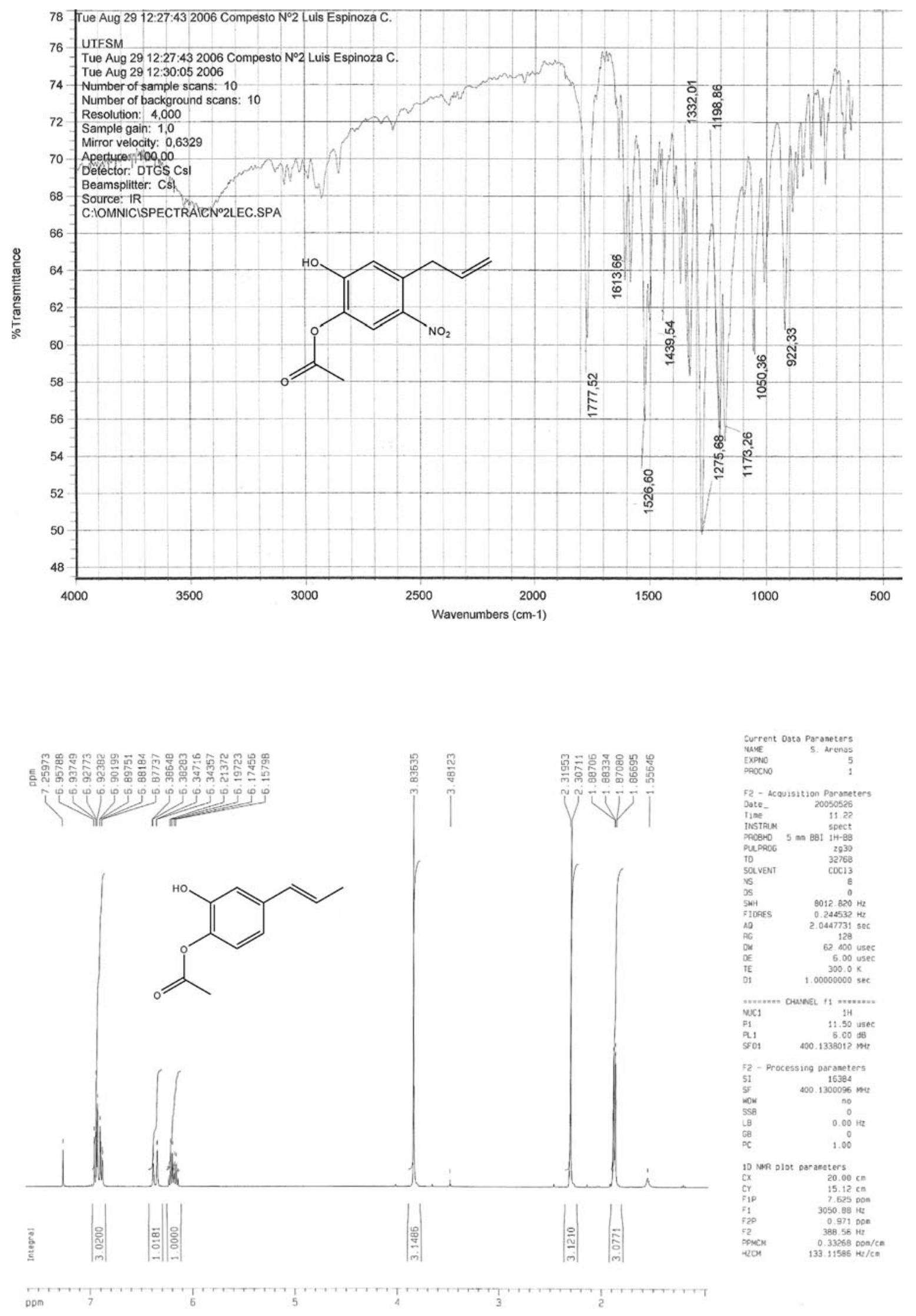

ppr 

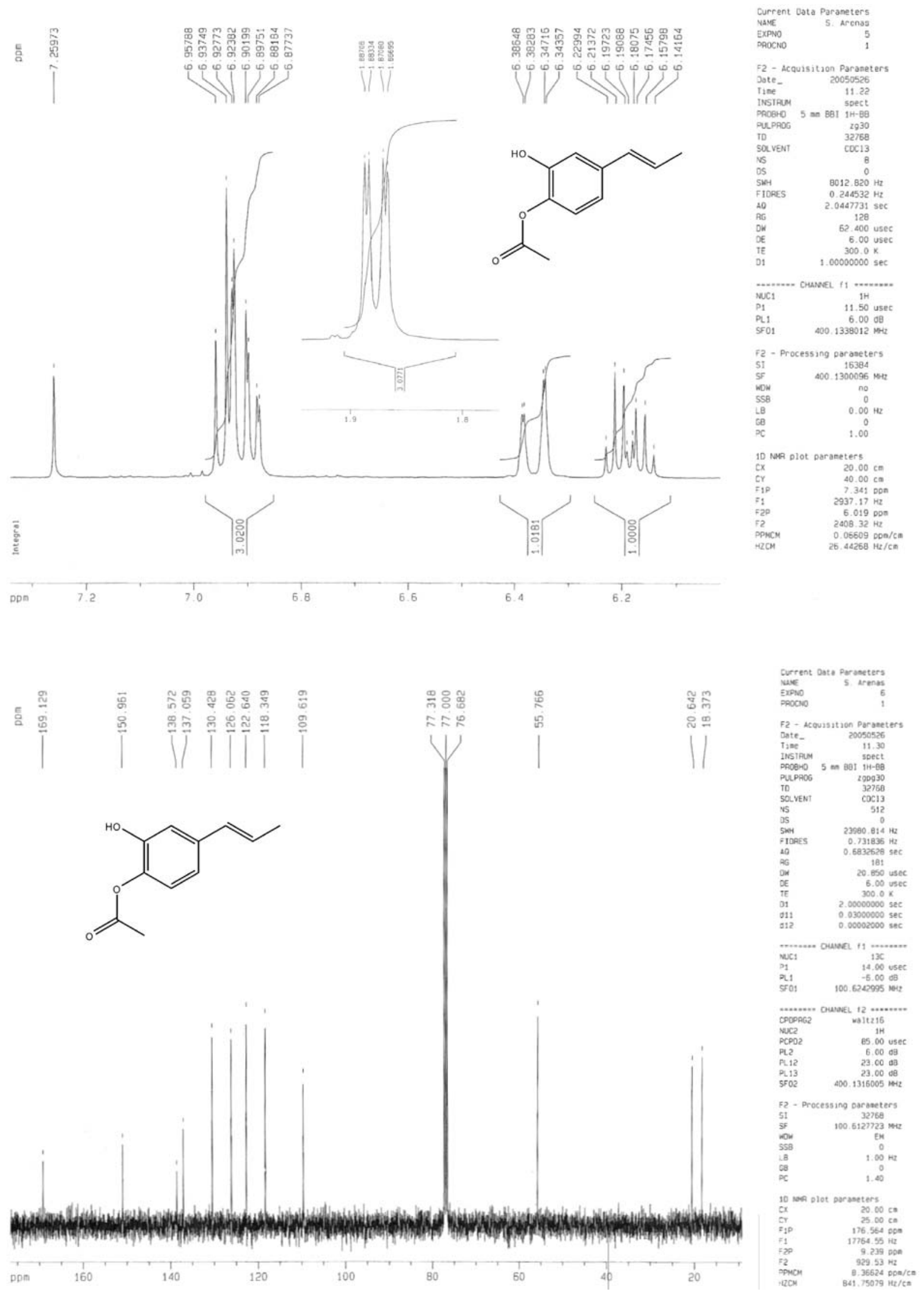


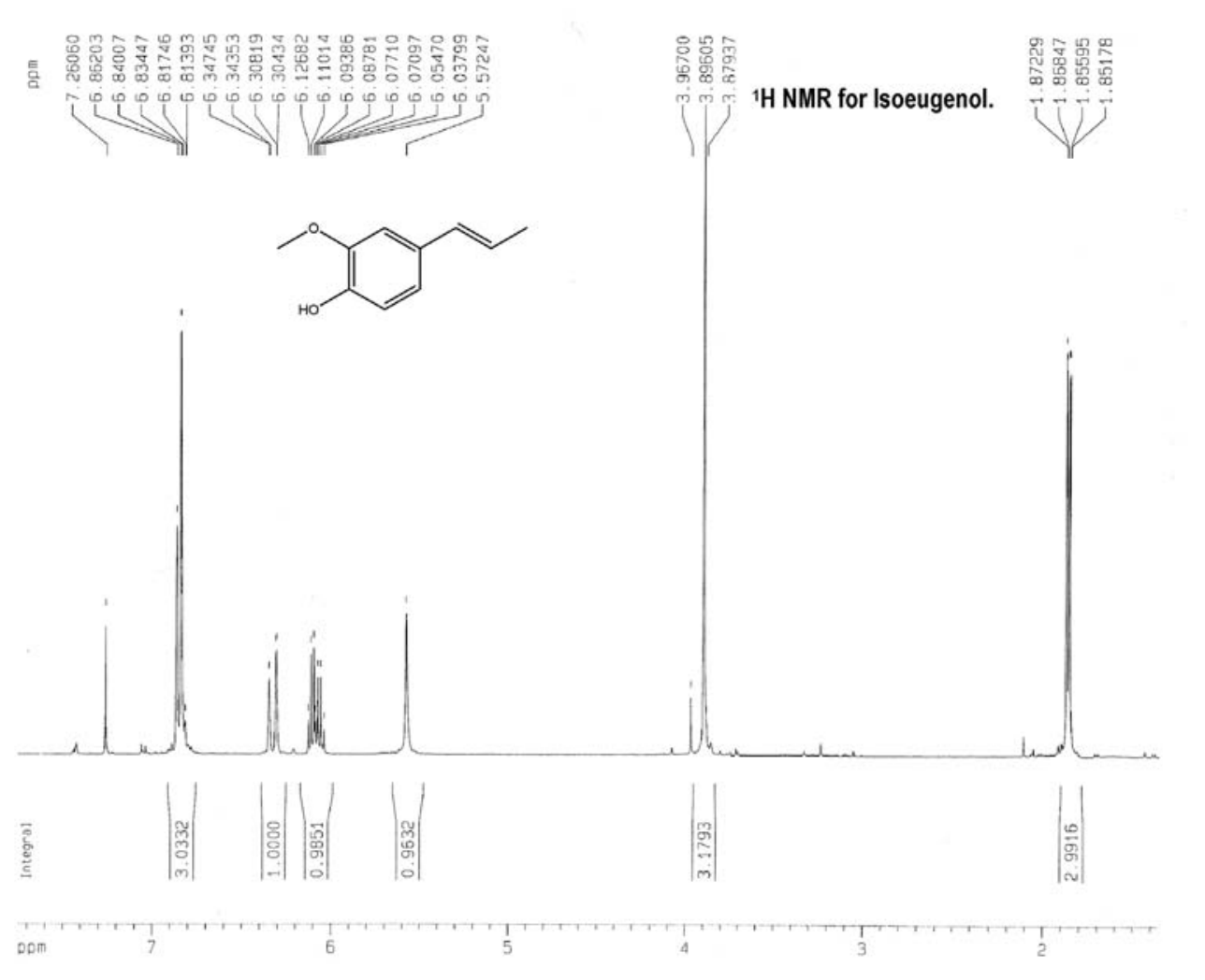

Current Dato Paraneters

NAFE
EXPNO

F2 - Acouistion Parameters
Dote- 20050510

Dote
Time

6.21
INSTRUM
spect

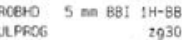

$\begin{array}{lr}\text { DD } & 32766 \\ \text { SOLVENT } & \text { CDC.13 } \\ 15 & 8\end{array}$

$0012.820 \mathrm{~Hz}$
$\mathrm{KHH}$

$0.244532 \mathrm{~Hz}$
$2.0447313 \mathrm{sec}$

14.3
$62.400 \mathrm{usec}$

6.00 usec
TE
TE
OE

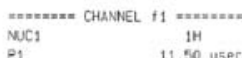

$\begin{array}{ll}P_{1} & 11.50 \text { uset } \\ \text { PL., } & 6.00 \text { oB }\end{array}$

F2 - Processing paraneters

$\begin{array}{lr}\text { SI } & 16384 \\ \text { SF } & 400.1300091 \\ \text { MHiz }\end{array}$

$\begin{array}{ll}\text { NOW } & \text { SSB } \\ \text { SSB } & 0\end{array}$

$\begin{array}{ll}\mathrm{LB} & 0.00 \mathrm{HL} \\ \mathrm{GB} & 0 \\ P \mathrm{C} & 1.00\end{array}$

10 nap olot parameters

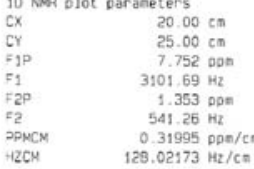

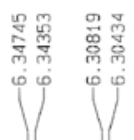

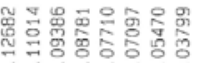

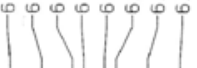

${ }^{1} \mathrm{H}$ NMR for Isoeugenol.
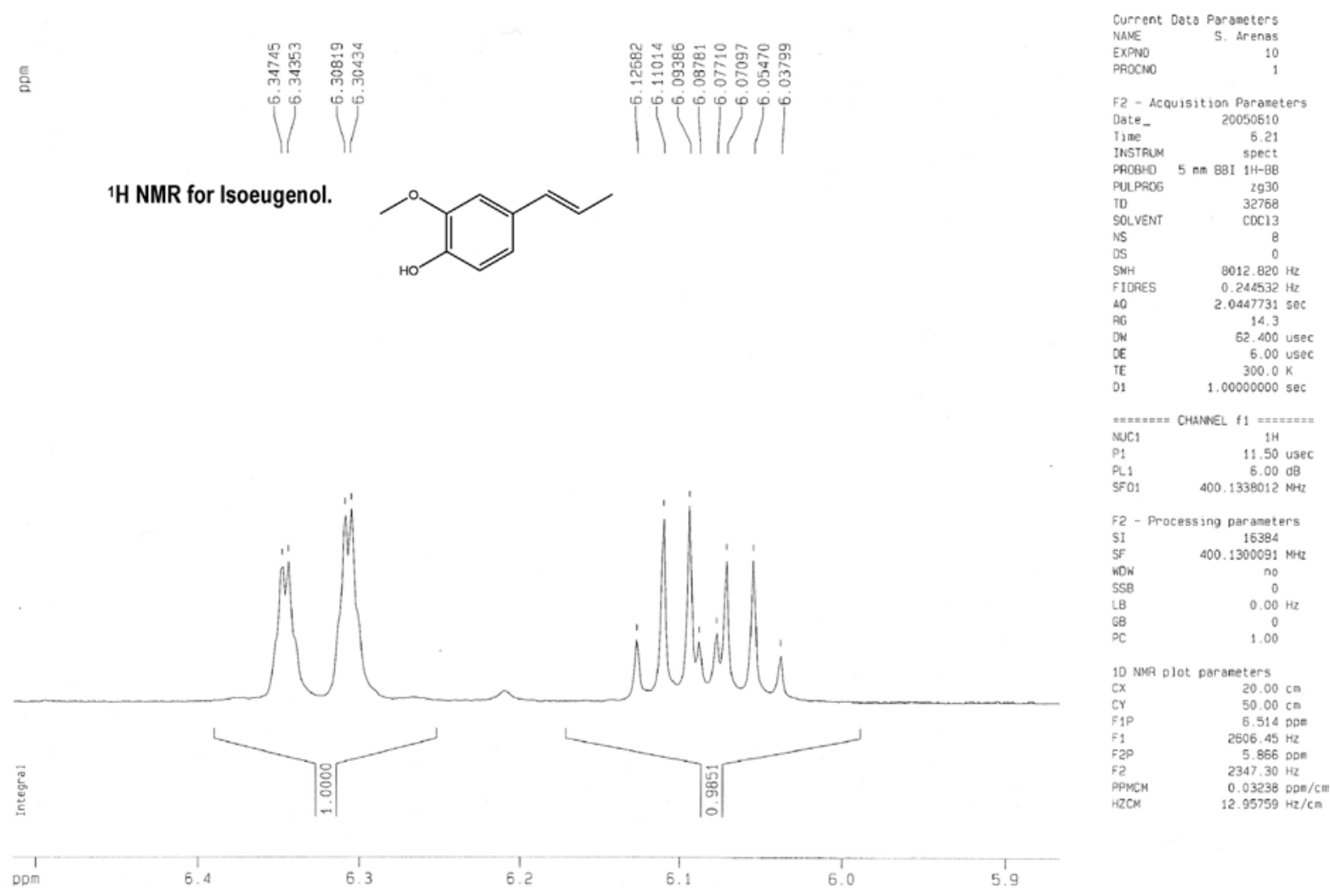

Dpm 


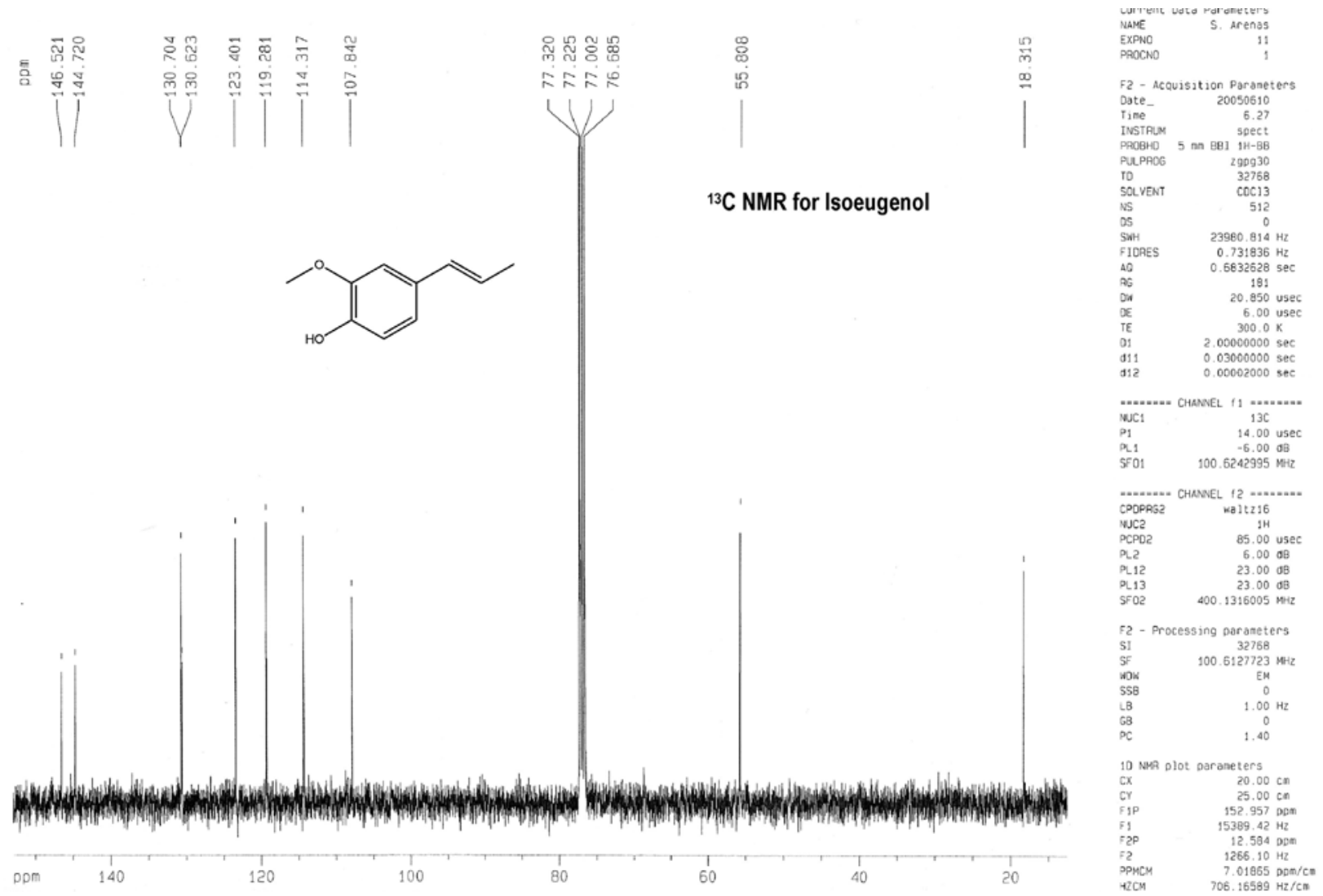

